

\section{Sumário}

EDITORIAL

Bruno Amaral Machado, Camilla de Magalhães Gomes e Soraia Mendes

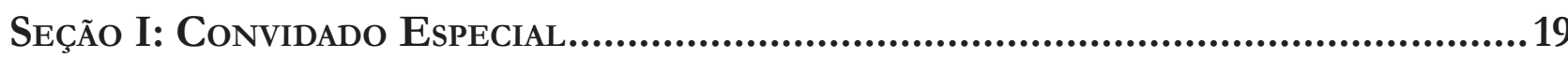

Autonomia Pessoal, Destino, julgamentos e instituições no Brasil: Notas Sobre uma PERGUNTA E ALGUMAS RESPOSTAS

Luiz Edson Fachin

SEÇÃo 2: Dossiê Temático....................................................................................40

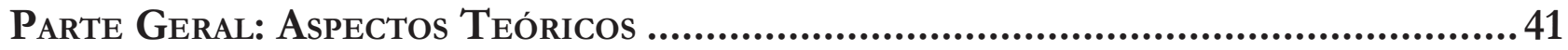

Raça e essencialismo na Teoria Feminista do Direito .......................................................43

Angela P. Harris, Tradução de Camilla de Magalhães Gomes e Ísis Aparecida Conceição

Políticas da morte: Covid-19 E Os Labirintos da Cidade Negra ........................................75

Ana Flauzina e Thula Pires

QUem PARIU AMÉFrica?: TRABALHO DOMÉSTICO, CONSTITUCIONALISMO E MEMÓRIA EM PRETUGUÊS

Juliana Araújo Lopes

O Lixo Vai Falar: Racismo, Sexismo e Invisibilidades do Sujeito Negro nas Narrativas de Direitos Humanos

Ciani Sueli das Neves

DiREITOS HUMANOS, DECOLONIALIDADE E FEMINISMO DECOLONIAL: FERRAMENTAS TEÓRICAS PARA A COMPREENSÃO DE RAÇA E GÊNERO NOS LOCAIS DE SUBALTERNIDADE

Rute Passos, Letícia Rocha Santos e Fran Espinoza

Direito, RAÇA E GÊNERO: ELEMENTOS PARA A CONSTRUÇÃo DE UMA TEORIA FEMINISTA DO DIREITO ADEQUADA AO FEMINISMO NEGRO

Mário Lúcio Garcez Calil e Debora Markman

"NeGras VAdiAs": A CRIMINALIZAÇÃo Do CORPO NEGRO QUE OUSA PROTESTAR.

Soraia da Rosa Mendes e Bruno Amaral Machado

A experiênCia do Abaetê Criolo como aÇão de enfrentamento a desigualdades de GÊNERO E RAÇA: UMA ANÁLISE DE DISCURSO SOBRE INTERSECCIONALIDADE

E FEMINISMO NEGRO

David Oliveira e Thalita Terto Costa 
ENTRE A AUSÊNCIA E O EXCESSO: A ATUAÇÃo DO ESTADO SOBRE CORPOS DISSIDENTES 230 Dayane do Carmo Barretos, Klelia Canabrava Aleixo e Vanessa de Sousa Soares

SILÊNCIOS E MITOS NUMA PERSPECTIVA INTERSECCIONAL: DO CONTROLE INFORMAL DE CORPOS AO CONTROLE PENAL DE MULHERES NEGRAS ......................................................248 Elaine Pimentel e Nathália Wanderley

Ministério Público e domínio Racial: poucas ilhas negras EM UM ARQuipélago nãoNEGRO 267

Saulo Murilo de Oliveira Mattos

Políticas públicas Para a ARTiCulaÇão de GÊNERo E RAÇA: MEIOS PARA GARANTir A REPRESENTATIVIDADE POLÍtiCA E JURÍDiCA DA MULHER NEGRA NO BRASIL 296 Mariana Dionísio de Andrade e Eduardo Régis Girão de Castro Pinto

Parte Específica: Incidências Concretas.......................................................... 317

REIMAGING THE POLICING OF GENDER VIOLENCE: LESSONS FROM WOMEN'S POLICE STATIONS IN Brasil AND ArgENTINA............................................................................................ 319 Kerry Carrington, Melissa Bull, Gisella Lopes Gomes Pinto Ferreira e María Victoria Puyol

NECROBIOPOLIÍtica DE GÊNERo No BRASIL CONTEMPORÂNEO: O FEMINICÍDIO EM TEMPOS DE FASCISMO SOCIAL 340 Maiquel Ângelo Dezordi Wermuth e Joice Graciele Nielsson

ViolÊNCIA CONTRA MULHERES QUILOMBOLAS: UMA REFLEXÃo SOBRE A APLICAÇÃo DE UMA PERSPECTIVA INTERSECCIONAL À LUZ DA IDEIA DE CONTRAPÚBLICOS SUBALTERNOS DELINEADA POR FRASER..... 360 Maria Eugenia Bunchaft, Leonardo Rabelo de Matos Silva e Gustavo Proença da Silva Mendonça

Políticas públicas de PREVEnÇÃo aO Feminicídio E INTERSECCIONALIDAdes . 384 Thiago Pierobom de Ávila, Marcela Novais Medeiros, Cátia Betânia Chagas, Elaine Novaes Vieira, Thais Quezado Soares Magalhães e Andrea Simoni de Zappa Passeto

DiREITO DE VIVER SEM VIOLÊNCIA: PROTEÇÃO E DESAFIOS DOS DIREITOS DAS MULHERES indígenas no Sistema InTERAmericano de Direitos Humanos Julia Natália Araújo Santos e Felipe Rodolfo de Carvalho

ANÁlise de GÊNERo E DE CRUZAMENTOS INTERSECCIONAIS DE UM PROGRAMA PARA AUTORES DE VIOLÊNCIA DOMÉSTICA CONTRA AS MULHERES

Mariana Fernandes Távora, Dália Costa, Camilla de Magalhães Gomes e Adriano Beiras

Controle PENAL dA LOUCURA E DO GÊNERO: REFLEXÕES INTERSECCIONAIS SOBRE MULHERES EgRESSAS DA MEdidA DE SEgurANÇA No Rio DE JANEIRO. .468 Bruna Martins Costa e Luciana Boiteux 
ONDE ESTÃo NOSSOS DIREITOS? O CAMPO FEMINISTA DE GÊNERO BORDADO PELAS MULHERES ATINGIDAS POR BARRAGENS

Tchenna Fernandes Maso e Tchella Fernandes Maso

Os SEGREDOS EPISTÊMICOS DO DIREITO DO TRABALHO.

Flávia Souza Máximo Pereira e Pedro Augusto Gravatá Nicoli

Reforma trabalhista e desigualdade de GÊNERo no Brasil: uMa PERSPECTIVA JuRÍdicA E ECONÔMICA

Natalia Branco Lopes Krawczun, Magno Rogério Gomes e Solange de Cassia Inforzato de Souza

A COLONIALIDADE DO PODER NA PERSPECTIVA DA INTERSECCIONALIDADE DE RAÇA E GÊNERO: ANÁLISE DO CASO DAS EMPREGADAS DOMÉSTICAS NO BRASIL .565

Daphne de Emílio Circunde Vieira Andrade e Maria Cecília Máximo Teodoro

COMPETIÇÃO POLÍTICA E DESIGUALDADES DE GÊNERO NAS ELEIÇÕES PARA ASSEMBLEIAS ESTADUAIS EM 2018

Lígia Fabris Campos, Décio Vieira da Rocha, Leandro Molhano Ribeiro e Vitor Peixoto

DisCrit: os LIMITES DA INTERSECCIONALIDADE PARA PENSAR SOBRE A PESSOA NEGRA COM DEFICIÊNCIA

Philippe Oliveira de Almeida e Luana Adriano Araújo

SeÇão III: Temais GeraIS

La Corte Interamericana de Derechos Humanos. Hermenéutica del derecho al MEDIO AMBIENTE SANO, A LA IDENTIDAD CULTURAL Y A LA CONSULTA, A LA LUZ DE LA SENTENCIA “Lhaka Honhat (nUestra tierra) vs. Argentina” (2020)

Juan Jorge Faundes Peñafiel, Cristobal Carmona Caldera e Pedro Pablo Silva Sánchez

LA RESPUESTA INSTITUCIONAL FRENTE A LA TRATA DE PERSONAS EN EL ESTADO DE CHIHUAHUA.

UN ANÁLISIS DE POLÍTICA PÚBLICA .676 Martha Aurelia Dena Ornelas

Comunidades quilombolas, RaCismo e ideologia no discurso de JAIr Bolsonaro: estudo CRÍTICO DOS DISCURSOS POLÍTICO E JUDICIAL 700 Ricardo de Macedo Menna Barreto e Helena Mascarenhas Ferraz

O Princípio Geral da Boa Administração no Código do Procedimento Administrativo Português. Pistas de inVestigação. 724 Ana Melro 


\title{
A colonialidade do poder na perspectiva da interseccionalidade de raça e gênero: análise do caso das empregadas domésticas no Brasil*
}

\author{
Coloniality within the perspective of the \\ intersectionality of race and gender: an \\ analysis of the case of domestic workers in Brazil
}

\author{
Daphne de Emílio Circunde Vieira Andrade** \\ Maria Cecília Máximo Teodoro***
}

* Recebido em 30/05/2020

Aprovado em 19/09/2020

** Mulher, negra, filha, amiga, feminista, trabalhadora, pesquisadora, advogada, eterna aprendiz. Mestranda em Direito Privado pela Pontifícia Universidade Católica de Minas Gerais. Bolsista CAPES pelo Programa de Excelência Acadêmica - Proex. Integrante do Grupo de Pesquisa RED - Retrabalhando o Direito, da PUC Minas, coordenado pelos Professores Doutores Maria Cecília Máximo Teodoro e Márcio Túlio Viana. Integrante do GEPROS - Grupo de Pesquisa e Extensão Capitalismo e Proteção Social na Perspectiva dos Direitos Humanos e Fundamentais do Trabalho e da Seguridade Social, da PUC Minas, coordenado pelo Professor Doutor Cléber Lúcio de Almeida. Lattes ID https://orcid.org/0000-0002-4239-6117

E-mail: deemilio@yahoo.com.br.

*** Mulher, mãe, professora, feminista. PósDoutora em Direito do Trabalho e da Seguridade Social pela Universidade de Castilla-La Mancha com bolsa de pesquisa da CAPES; Doutora em Direito do Trabalho e da Seguridade Social pela USP- Universidade de São Paulo; Mestre em Direito do Trabalho pela Pontifícia Universidade Católica de Minas Gerais; Graduada em Direito pela PUC/MG; Professora de Direito do Trabalho do Programa de Pós-Graduação em Direito e da Graduação da PUC/MG; Professora Convidada do Mestrado em Direito do Trabalho da Universidade Externado da Colômbia. Pesquisadora; Líder do Grupo de Estudo RED - Retrabalhando o Direito, vinculado à RENAPEDTS; Autora de livros e artigos. Advogada. Lattes ID http:/ lattes.cnpq.br/7521600430933892

E-mail: mariaceciliamaximoteodoro@gmail.com

\section{Resumo}

A proposta do presente artigo é pesquisar as origens do pensamento decolonial com base no surgimento do Grupo Modernidade/Colonialidade, a fim de entender como o processo de expansão dos territórios dos países da Europa Ocidental sobre os países do chamado Sul Global culminou na colonização não somente dos corpos, mas dos saberes e das mentes dos dominados. A partir das reflexões de autores decoloniais, como Aníbal Quijano e Maria Lugones, debatemos o surgimento do feminismo decolonial e sua importância para o desenvolvimento pessoal das oprimidas que se encontram nas fronteiras limites entre o obscurantismo da sociedade e o seu próprio sofrimento. Diante dessa análise e tendo como referencial as relações de trabalho, concluímos que as ações opressoras se perpetuam no mundo pós-colonial sobre os sujeitos e sujeitas subalternas e são mais intensas quando se analisa a interseccionalidade de raça e gênero. Na sequência, propomos uma breve análise normativa do trabalho das empregadas domésticas no Brasil, bem como apresentamos um retrato desse mercado de trabalho, concluindo que sobre elas ainda pesa a opressão "das gentes" e do capital. Por fim, pontuamos uma última reflexão sobre a situação dessas sujeitas, especialmente no momento em que se vive a pandemia causada pelo Coronavírus. A pesquisa utiliza-se da produção acadêmica de autores e autoras alinhadas com o pensamento epistemológico decolonial, também como forma de contribuir para a ruptura com o padrão eurocêntrico do saber e reconhecer a importância do surgimento de uma nova proposta, que seja de complementariedade e não de exclusão.

Palavras-chave: Decolonialidade. Raça e Gênero. Feminismo. Direito do Trabalho. Domésticas. Coronavírus.

\section{Abstract}

The present article's main aim is to use the decolonial thought that comes with the emergence of the Modernity / Coloniality, in order to understand how the process of expansion of Western Europe's territories in the Global 
South culminated over the centuries in the colonizing not only of bodies, but of flavors and minds of the ones who were forcefully dominated. Based on the reflections of decolonial author, such as Aníbal Quijano and Maria Lugones, this article discusses the rise of decolonial feminism and its importance for the personal development of the oppressed, who find themselves in the vicinity of society's obscurantism and their own individuality. Through this analysis - having labor relations as a reference - the present work concludes that oppresion is perpetuated against subjects in the post-colonial world, taking into consideration that this same oppresion is even more intense when the intersectionality of race and gender is taken into account. Therefore, we propose a brief normative analysis of domestic labour in Brazil, presenting a portrait of this labour market, concluding these subjects are still inevitably victmized by "the people" and the capital. Finally, this article presents one final reflection on the situation of domestic workers, taking into consideration the severity of the current Covid19 pandemic and its immediate consequences in this field. Finally, this research is based on academic works by authors in line with decolonial epistemological thinking as a way of contributing to a break with the eurocentric knowledge standard and recognizing the importance of the emergence of a new scientific proposal, which should complementarity and not exclusionnary.

Keywords: Decoloniality. Race and gender. Feminism. Labor Law. Domestic workers. Covid19

Que um homem não te define Sua casa não te define Sua carne não te define Você é seu próprio lar

Triste, Louca Ou Má - Francisco, el Hombre

\section{Introdução}

Brasil! A primeira palavra quando se pensa nessa nação é a diversidade. Sim, trata-se de um povo com diferentes matrizes culturais, dos índios aos imigrantes, dos escravos aos seus descendentes. No entanto, com base em qualquer recorte que se estude a sociedade brasileira, não se pode omitir seu passado colonial e escravocrata ${ }^{1}$.

A colonialidade é fruto da modernidade, porque marca toda a história do desenvolvimento de nossa nação, instaurando-se no presente sob novas formas de dominação que vão além da exploração das terras e da imposição do modo de vida do colonizador ao colonizado. Na América Latina, estudiosos e estudiosas do Grupo Modernidade e Colonialidade foram os primeiros a propor reflexões sobre as diferentes formas de opressão dos grupos subalternizados e como elas se manifestam na pós-modernidade.

Dessa matriz de pensamento, extraem-se as ideias sobre a colonialidade do poder, do saber e do ser. São outras, não tão novas assim, maneiras de perpetuar, no imaginário dos sujeitos e das sujeitas, a existência de um padrão universal de cultura. Trata-se de uma figura referencial para os demais, que invariavelmente recai sobre o homem, branco, europeu, heterossexual e cristão, o qual tem na sociedade, às vezes inconsciente do seu papel transformador, um fio condutor e reprodutor de opressão.

Na ponta desses mecanismos de dominação pelo saber, pela referência do ser e pelo poder estão as mulheres pretas e pardas, pobres, como sujeitas invisibilizadas em determinados aspectos da organização social, mas explorados em tantos outros. Por isso, não é coincidência que um importante desdobramento sobre os

Cf.: FREYRE, Gilberto. Casa-grande \& Senzala: formação da família brasileira sob o regime da economia patriarcal. 48 ed. São Paulo: Global, 2003. 
estudos decoloniais tenha como recorte a interseccionalidade de gênero e raça. Nesse sentido, destaca-se o trabalho da filósofa argentina Maria Lugones reconhecida por sua contribuição para o estudo da colonialidade do conceito de gênero e suas implicações.

A proposta de Lugones revela como as estruturas de poder enraizadas na sociedade latino-americana perpetuam as sujeitas subalternas, em sua maioria pretas e pardas, como minorias frente aos indicadores de desenvolvimento social, econômico e político. E essa realidade tem rostos, tem nomes e tem lugares já previamente designados para serem ocupados na divisão do trabalho do mundo capitalista.

Na sociedade brasileira, o trabalho reprodutivo remunerado é predominantemente prestado por domésticas e diaristas, sendo inegável o papel ocupado por elas em nossas vidas, em relação ao cuidado com pessoas. Não obstante essa tarefa tenha um significado abstrato, tem se revelado bastante palpável nos tempos da pandemia pelo novo Coronavírus. Por isso, tanto no Brasil como em outros países muito se discute sobre a essencialidade de algumas profissões e sobre a necessidade de incentivar o autocuidado.

Verifica-se o crescimento dos debates para rever a divisão sexual do trabalho, cujos números sempre apontaram para a sobrecarga de horas semanais dedicadas pelas mulheres em comparação aos homens nas tarefas de cuidado. Todavia, paralelamente a isso, propomos intensificar esse olhar sobre o trabalho das domésticas e diaristas, considerando as recentes medidas legislativas de algumas cidades e Estados brasileiros que incluíram esse trabalho como atividade essencial, portanto, excluindo essas trabalhadoras das medidas de isolamento social indicadas pela Organização Mundial da Saúde como forma de preservação da vida face ao alastramento do Coronavírus.

Para aprofundar essa reflexão, a discussão se inicia na Seção 2 com a conceituação de colonialidade na modernidade, com base nas lições de Aníbal Quijano, um dos fundadores do Grupo Modernidade/Colonialidade. Em seguida, a colonialidade do gênero de Maria Lugones é explorada na Seção 3, complementando o estudo sobre as modernas formas de opressão sobre as mulheres e a necessidade de um feminismo que dialogue com essas questões.

Essa relação da interseccionalidade de gênero e raça é exemplificada na Seção 4 com um breve estudo sobre as regras de proteção para as empregadas domésticas brasileiras. Na sequência, debatem-se, na Seção 5, os dados relativos ao trabalho doméstico com base na interseccionalidade de raça e gênero a fim de averiguar como os fatores característicos desses trabalhos reforçam ou não a subalternização dessas sujeitas perante a sociedade brasileira.

Por último, na Seção 6, propõe-se a investigação de alguns dos principais efeitos sobre o trabalho das domésticas durante a pandemia por Coronavírus. Essa análise tem como referencial os relatos dessas trabalhadoras, os quais têm como alguns de seus interlocutores os movimentos sociais representados pelos Sindicatos da categoria e a Federação Nacional das Empregadas Domésticas - FENATRAD. Somam-se a esse grupo a Agência da Organização Internacional do Trabalho no Brasil - OIT-Brasil e o Ministério Público do Trabalho - MPT; todos importantes para a construção do diálogo que se propõe a seguir, de combate às discriminações por raça e gênero nas relações de trabalho.

\section{Breves apontamentos sobre o estudo da decolonialidade e a colonialidade do saber, do ser e do poder}

Na América Latina, a expressão decolonialidade foi trabalhada inicialmente pelo Grupo Modernidade/ Colonialidade iniciado a partir dos estudos acadêmicos de Aníbal Quijano e Walter Mignolo, a quem outros importantes nomes do saber se agregaram, como Enrique Dussel e Imanuel Wallerstein². Seu ponto de par-

\footnotetext{
2 Não se ignora que os estudos sobre pós-colonialismo tenham origem em alguns grupos de Universidades localizadas na Inglaterra e
} 
tida é a construção de uma desobediência epistêmica ao modo de pensar tido como racionalizado, homogeneizante e com pretensões universais, todo ele construído com base na ideia de um conhecimento total de matriz eurocêntrica que teve como marco histórico a descoberta do "Novo Mundo" no final do século XV.

O colonialismo foi a consequência do imperialismo europeu que culminou na conquista dos territórios das Américas, da África e de parte da Ásia. Seu intuito foi instaurar e perpetuar o controle sobre os locais descobertos o que implicava a necessidade de subverter as estruturas sociais dos povos originários. Esse foi o início de um tempo que se denominou modernidade ${ }^{3}$, marcado por uma dominação direta e política sobre povos não europeus. Um colonialismo que, rapidamente, evoluiu para a colonialidade das esferas do saber, do ser e do poder dessas sociedades ${ }^{4}$.

Pode-se afirmar que as primeiras formas de repressão sobre os colonizados recaíram sobre suas fontes de saber, o modo como produziam conhecimento com base nos ensinamentos dos ancestrais, orientados por comunicações recíprocas entre os sujeitos regionais, mas que não esvaziavam os significados de seus símbolos e imagens locais. Esses modos de reconhecimento de saberes locais, os quais permitiam aos povos originários identificarem-se como semelhantes, foram ofuscados e substituídos pelo pensamento conforme o padrão cultural europeu ou, em sentido mais amplo, padrão ocidental.

São exemplos dessa situação os casos de apagamento de saberes ou mesmo a negação do importante conhecimento nas áreas de agricultura, astrologia, astronomia, engenharia, geografia, geometria, matemática e saúde pelos ameríndios, pelos negros africanos e pelas civilizações pré-colombianas (maias, astecas e incas). Em seu lugar, introduz-se a ideia de um conhecimento puro, produzido isoladamente, que para ser válido deve ao mesmo tempo ser imparcial, neutro, proposto por sujeitos hierarquicamente superiores em relação aos seus objetos de pesquisa e comprovado segundo métodos cartesianos.

Trata-se de um processo individualista, que se esconde atrás da premissa de uma racionalidade, nega a totalidade de saberes ou promove uma verdadeira "pilhagem de conhecimentos" a que se refere Boaventura de Sousa Santos ${ }^{5}$. Sua pretensão é se tornar universal, hierarquizante e, portanto, forte o suficiente para tor-

nos Estados Unidos da América, cuja proposta era descontruir a lógica do eurocentrismo acadêmico e investigar criticamente a formação de concepções dominantes da modernidade e suas fontes de opressão no passado colonial, a partir de um novo discurso social, próprio dos sujeitos que foram colonizados, especialmente os indianos, asiáticos e os norte-americanos. Entretanto, a menção à decolonialidade, como sendo uma expressão trabalhada pelo Grupo Modernidade/Colonialidade, refere-se à ruptura iniciada em 1998 por Mignolo ao que denominou "imperialismo" nos estudos culturais, subalternos ou pós-coloniais. Mignolo defendeu que as bases de dominação continuavam a se perpetuar nos estudos sobre o pós-colonialismo, porque tinham como referencial o Império Britânico, como se as heranças de seus coloniais pudessem ser replicadas e teorizadas nos estudos do pós-colonialismo da América Latina. MIGNOLO, Walter. Postoccidentalismo: el argumento desde América Latina. Em: CASTRO-GÓMEZ, Santiago \& MENDIETA, Eduardo (coords.). Teorías sin disciplina: latinoamericanismo, poscolonialidad y globalización en debate. México: Miguel Ángel Porrúa, pp. 26-49, 1998. Disponível em: http:// people.duke.edu/ wmignolo/InteractiveCV/Publications/Teoriassindisciplina.p-df Acesso em: 17 mai.2020, p. 26.

3 Nesse sentido, Enrique Dussel defende a tese que a modernidade tem dois conceitos. O primeiro marca um período de desenvolvimento do ser humano, que saindo do obscurantismo do período medieval, passa a ser guiado pela razão e cujos marcos históricos incluem o Renascentismo Italiano entre os séculos XIV e XVI e a Revolução Francesa no século XVIII. Nesse sentido, a Europa é o local onde ocorre essa transformação. O outro conceito entende a modernidade a partir de uma visão global, o qual tem como histórico o processo de expansão dos Impérios Europeus para o descobrimento de outros mundos. Inicia-se com as expedições de portugueses e espanhóis no século XV, desde o Oriente até o descobrimento da América em 1492, ano que significa o "marco temporal" da formação de um "Sistema-mundo". Isso, porque, a partir dessa "integração" se pode contar a história, não obstante seus referenciais sejam o colonialismo e o eurocentrismo. DUSSEL, Enrique. Europa, modernidad y eurocentrismo. Em: LANDER, Edgardo (coord.). La colonialidad del saber: eurocentrismo y ciencias sociales, perspectivas latino-americanas. Buenos Aires: Clacso, pp. 24 a 33, 2000. Disponível em: http://biblioteca.clacso.edu.ar/clacso/sur-sur/20100708040738/4_dussel.pdf Acesso em 17 mai. 2020.

4 Sobre a diferença entre colonialismo e colonialidade Aníbal Quijano explica que o colonialismo se refere a " [...] uma relação de dominação direta, política, social e cultural dos europeus sobre os conquistados de todos os continentes. Essa dominação se conhece como colonialismo". A colonialidade constitui “[...] o modo mais geral de dominação no mundo de hoje, uma vez que o colonialismo como uma ordem política explícita foi destruído". Tradução livre. QUIJANO, Aníbal. Colonialidad y modernidadracionalidad. Perú Indígena, ano 29, pp. 11-20, 1992. Disponível em: https://www.lavaca.org/wp-content/uploads/2016/04/quijano. pdf Acesso em: 17 mai. 2020.

Cf.: SANTOS, Boaventura de Sousa. Para além do pensamento abissal: das linhas globais a uma ecologia de saberes. Novos estud. CEBRAP, São Paulo, n. 79, pp. 71-94, Nov. 2007. Disponível em: http://www.scielo.br/scielo.php?script=sci_arttext\&pid=S010133002007000300004\&lng=en\&nrm=iso Acesso em 17 mai. 2020. 
nar subalternos os povos que não são orientados por essa lógica.

Como parte desse primeiro movimento, o aniquilamento do saber avança sobre o imaginário dos sujeitos colonizados. É um processo que vai além dos saberes, porque interfere no próprio processo de autorreconhecimento dos povos originários, substituindo seus referenciais de cultura por outros, apontados como melhores, tanto intelectual quanto visualmente.

Não basta o esvaziamento das memórias desses corpos. Os colonizadores impõem, ainda, diferentes formas de exteriorizar esses padrões de expressão. Trata-se do uso da vestimenta, da linguagem correta, do culto religioso cristão, da superioridade do homem em relação às mulheres e às crianças ${ }^{6}$, do trabalho como forma de progresso material ${ }^{7}$, entre outros.

Desse modo, o colonialismo atinge um essencialismo, na medida em que o poder se manifesta sob diferentes formas nas relações sociais. Acerca das instâncias em que é possível identificá-lo, Quijano ${ }^{8}$ explica que:

como o conhecemos historicamente, em uma escala social, o poder é um espaço e uma malha de relações sociais de exploração / dominação / conflito articulado basicamente com base e em torno da disputa sobre controle das seguintes áreas da existência social: (1) o trabalho e seus produtos; (2) dependendo do primeiro, a "natureza" e seus recursos de produção; (3) sexo, seus produtos e a reprodução das espécies; (4) a subjetividade e seus produtos, materiais e intersubjetivos, incluindo conhecimento; (5) a autoridade e seus instrumentos, em particular a coerção, para garantir a reprodução desse padrão de relações sociais e regular suas mudanças.

Não obstante a resistência em alguma medida desses povos colonizados, a conjunção de fatores de dominação política - que englobava a produção econômica e cultural — rapidamente toma conta da sociedade em todos os seus vieses. E se transmuta em outro padrão de colonialismo, agora mais complexo, porque insere na mentalidade dos povos não-europeus o desejo ${ }^{9}$ de pertencerem ao outro lado, moldado como moderno e melhor. Esse modelo é o do homem europeu, branco, heterossexual, cristão e burguês, que compõe no imaginário de outros sujeitos a expressão máxima do poder.

Para ascender a uma parcela desse poder, os colonizados sujeitam-se a determinadas condições, cujas formas de implantação e suas consequências compõem o conceito da colonialidade na pós-modernidade, não mais do saber e do ser, mas também de poder. Sua marca principal é delimitar os grupos dos dominantes e dos dominados, das maiorias e das minorias sob o ponto de vista da distribuição do poder político, econômico e cultural nas sociedades conforme critérios fictícios definidos como "raças", "et-

\footnotetext{
${ }^{6}$ "Nesse sentido, Vieira Andrade destacou em estudos preliminares que “ [...] Aristóteles dispôs ser a mulher, em termos de classe, nada diferente de um escravo. Dessa forma, tanto a mulher quanto os escravos seriam desprovidos de uma racionalidade necessária para o "mando" e para a administração da polis. Além disso, a mulher estaria confinada à vida doméstica, âmbito ao qual ela pertence naturalmente de acordo com Aristóteles, haja vista a sua inevitável inferioridade em relação ao homem". Cf.: BASTOS, Angélica Barroso; COSTA, Bárbara Amelize; VIEIRA ANDRADE, Daphne de Emílio Circunde; DAHAS, Débora Caetano; SOUTO, Gisleule Maria Menezes. Insurreição gênero nos espaços de poder: A representatividade feminina na política brasileira à luz da reforma eleitoral. Belo Horizonte: Motres, pp. 24-25, 2018.

Cf.: ARISTÓTELES. A política. São Paulo: Martin Claret, 2001.

Felice Battaglia, analisando os sentidos dados pelos economicistas ao trabalho explica que ele se apresenta, juntamente com a terra e o capital, como um fator de produção. Essa visão de trabalho, portanto, faz alusão ao sentido econômico que se dá ao trabalho, aquele que, em certa medida, exclui da sua compreensão seus fins e utilidades éticas e espirituais BATTAGLIA, Felice. Filosofia do Trabalho. São Paulo: Saraiva, pp. 19-22, 1958.

8 Cf.: QUIJANO, Aníbal. "Colonialidad del poder y clasificación social”. Journal of world-systems research, v. 11, n. 2, p. 345, 2000. Tradução livre. Disponível em: https://www.lavaca.org/wp-content/uploads/2016/04/quijano.pdf Acesso em: 17 mai. 2020.

9 Quijano explica que os colonizadores europeus inseriam seu modo de ser na vida dos colonizados e empreendiam maneiras de cooptá-los, dominando-os. Utilizavam-se, para isso, do desejo dos dominados de acesso ao poder. Segundo o autor: "Os colonizadores também impuseram uma imagem confusa de seus padrões próprios de produção e significados do conhecimento. Eles os colocaram, primeiro, longe do acesso dos dominados. Mais tarde eles foram ensinados parcial e seletivo, para cooptar alguns dominados em alguns casos do poder dos dominadores. Então, a cultura europeia também se tornou uma sedução: dava acesso ao poder. Afinal, além da repressão, o principal instrumento de todo poder é sua sedução. Europeização cultural tornou-se uma aspiração”. Tradução livre. QUIJANO, Aníbal. Colonialidad y modernidad-racionalidad. Perú Indígena, ano 29, pp. 12-13, 1992. Disponível em: https://www.lavaca.org/wp-content/uploads/2016/04/quijano.pdf Acesso em: 17 mai. 2020.
} 
nias" e "os grupos nacionais" 10.

A partir dessa lógica, é comum que os sujeitos subalternos dos tempos coloniais, discriminados em relação aos agentes dominadores, ocupem atualmente os lugares de menor poder na pirâmide social, o que perpetua a consequente discriminação em relação aos que estão no topo. Pode-se perceber esse padrão tanto em nível local (nacionais versus estrangeiros), interpessoal (homens versus mulheres), quanto global (centro versus periferia) ${ }^{11}$.

Nos tempos atuais, ainda que a dominação política formal dos antigos impérios não se estenda de igual modo sobre as ex-colônias como consequência principalmente da superioridade militar daqueles, o mesmo não se pode dizer das formas de controle econômico, cultural e social, as quais permanecem. O novo colonialismo é a continuidade de um processo anterior que se utiliza de novas maneiras de subjugar os povos, agora em uma escala macro e global, impulsionada pelo sistema econômico capitalista e cujos agentes são os descendentes euro-norte-americanos, atuais sucessores do antigo centro de poder da cultura ocidental.

Vive-se então um novo imperialismo que tem na colonialidade, e não mais no colonialismo político-militar, uma confluência de formas diversas de dominação, as quais reafirmam os padrões anteriores, mas também avançam com novas mentalidades sobre os corpos e as mentes de grupos tidos como subalternos. Trata-se uma "colonialidade de poder" ${ }^{12}$ que enforma a sociedade. Em sua base possui o fetiche do trabalho produtivo, do padrão de consumo como felicidade, da igualdade de gênero entre os indivíduos, da universalidade do conhecimento e da cultura ${ }^{13}$.

O movimento da decolonialidade ${ }^{14}$ propõe recuperar e debater as relações intersubjetivas baseadas na

\footnotetext{
10 Quijano critica a ideia da discriminação dos sujeitos em raça e classe, porque entende que é uma construção do próprio processo de dominação, tal como uma estratégia para manter o poder dos europeus sobre os povos colonizados e que se perpetua na colonialidade dos tempos atuais. Para ele: "De fato, se as principais linhas da exploração e dominação social em escala global, as principais linhas de poder mundo atual, sua distribuição de recursos e trabalho entre a população da mundo, é impossível não ver que a grande maioria dos explorados, os dominados, dos discriminados, eles são exatamente os membros das "raças", dos "grupos étnicos", dos "países" em que as populações foram categorizadas, colonizadas, no processo de formação dessa potência mundial, desde a conquista da América em diante". Tradução livre. QUIJANO, Aníbal. Colonialidady modernidad-racionalidad. Perú, Indígena, ano 29, 1992, p. 12. Disponível em: https://www.lavaca.org/wp-content/uploads/2016/04/quijano.pdf. Acesso em: 17 mai. 2020.

11 Essa divisão pela polaridade é um dos traços do colonialismo e da colonialidade moderna que, pensado à luz das relações sociais, significa colocar em lados opostos homens e mulheres, cristãos e mulçumanos, etc. Pensado sob a ótica do sistema global, significa repartir o mundo em países do eixo Norte, que se intitulam como socialmente mais desenvolvidos, racionais, superiores e, do eixo Sul, os quais são vistos como atrasados economicamente, não-civilizados. Os primeiros compõem o centro, hoje representados pelos países da Europa Ocidental, e os demais formam a periferia, a saber: América Latina, África, países mulçumanos e do Sul da Ásia. 12 Quijano explica que o colonialismo se instaura em uma estrutura global, porque tem como principal articulador o poder. Aqueles que detêm o poder (hierárquico, espiritual, sobre os meios de produção ou do conhecimento epistêmico) são os dominantes, enquanto os outros, seus dominados. QUIJANO, Aníbal. Colonialidad del poder y clasificación social. Journal of world-systems research, v. 11, n. 2, 2000, p. 342-386. Disponível em: https://www.lavaca.org/wp-content/uploads/2016/04/quijano.pdf Acesso em: 17 mai. 2020 .

13 Sobre o colonialismo, Cléber Lúcio de Almeida e Wânia Guimarães Rabello Almeida argumentam que o neoliberalismo atua até mesmo sobre a subjetividade dos trabalhadores, cooptando-se para o aumento da produtividade: "[...] para envolver os trabalhadores na busca dos desejos do capital, o capitalismo utiliza a produção e mobilização de afetos, ou seja, o poder de gerar normas através dos afetos. Dessa maneira, essas relações afetivas funcionam como base para a adesão dos trabalhadores aos desejos de capital”. ALMEIDA, Cléber Lúcio de.; Almeida, Wânia Guimarães Rabêllo de. El capitalismo neoliberal y la alienación subjetiva y colonial de los trabajadores: Deseos y afectos en el mundo del trabajo. Revista chilena de Derecho del Trabajo y de la Seguridad Social. Vol. 10. Núm. 20, pp. 1-21, 2019. Disponível em: https://revistatrabajo.uchile.cl/index.php/RDTSS/article/view/54227/59293 Acesso em: 07 mar. 2020.

E, também, nesse sentido: "É justamente aqui que parece residir a felicidade como insumo da nova mais-valia. Quando o trabalhador é forçado a "vestir a camisa da empresa", a "amar o que faz", ele nem ao menos sente que trabalha, se dociliza e aceita todas e quaisquer situações, deixando de realizar, na qualidade de ser humano, nos âmbitos pessoal e social, atividades de lazer, bem como a convivência familiar e social". TEODORO, Maria Cecília Máximo; OLIVEIRA, M. P. S. Felicidade: A mais-valia da modernidade líquida. Em: V ENCONTRO DA RENAPEDTS - Rede Nacional de Grupos de Pesquisa e Extensão em Direito do Trabalho e Seguridade Social, 2019, Rio de Janeiro. TRABALHO, DEMOCRACIA E DIREITOS: Desafios epistêmicos para a desmercantilização do labor humano. Belo Horizonte: Virtualis, 2019. v. 1. pp. 286-287.

14 Nos estudos acadêmicos, verifica-se com mais frequência o uso da expressão decolonialidade. No entanto, também se utiliza o termo descolonialidade. Essa última palavra remonta à ideia de descolonizar, como ato ou efeito de romper com a tradição do con-
} 
reciprocidade do conhecimento, nos saberes locais e regionais, tidos como não científicos, muitos deles ignorados ou aniquilados em razão da prática colonial do poder. E, além disso, permite uma interconexão de elementos às vezes ignorados para a construção do conhecimento acadêmico, como a ideia de raça, classe, sexo e gênero enquanto fatores de discriminação nas sociedades atuais, pensados sob uma perspectiva dos povos latinos e das suas particularidades.

\section{Feminismo e colonialidade de gênero consoante Maria Lugones}

Em seus estudos, a decolonialidade considera a pluralidade das existências que atravessa os tempos e os espaços. Forma uma linha de pensamento contra hegemônica, não pela mera desobediência epistemológica, mas para revelar outros conhecimentos preexistentes à era da modernidade, mas que foram apagados ou desacreditados. Nesse sentido, constitui-se um despertar das resistências contra os padrões relacionados a raça, classe, sexualidade e gênero. Por isso, os movimentos negro e feminista são importantes desdobramentos dessa pesquisa acadêmica.

Consciente disso, a pesquisadora argentina Maria Lugones dedicou-se ao estudo do feminismo, integrando o grupo Modernidade/Colonialidade. Para a autora, a colonialidade de gênero integra o conceito de colonialidade, mas não se resume às perspectivas setoriais apresentadas por Quijano. Ao menos não, caso se entendam que essas categorias sejam estanques e incomunicáveis. Por isso, Lugones propôs aprofundar os debates apresentados por Quijano para além dos sentidos da colonialidade de poder por meio do estudo de um feminismo que seja diferente do "feminismo de perfumaria" 15 .

Sobre o feminismo, o nível dos debates acadêmicos permite-nos compreender a grandeza da luta das mulheres e, ao mesmo tempo, afirmar que vários são os "feminismos" e suas reivindicações, exatamente porque elas sofreram e sofrem diferentes formas de opressão. Nesse sentido, é possível identificar diferentes tipos de movimentos das mulheres ao longo da história, que a literatura tentou enquadrar como "ondas" do feminismo e cujas reivindicações eram ora centralizadas e homogeneizantes, ora difusas e heterogêneas.

No entanto, o exame de seus contextos e reinvindicações não autoriza concluirmos que entre eles não há correlação. Ao contrário, existe uma certa interconexão entre as questões que suscitam, valendo anotar que a luta feminina é por inclusão e está além das fronteiras dos países em que elas (as mulheres) vivem ${ }^{16}$.

Nesse sentido, o feminismo decolonial de $\operatorname{Lugones}^{17}$ é mais uma importante reflexão, porque dá um passo adiante ao examinar situações concretas sob o ponto de vista da interseccionalidade de raça, classe e gênero. Isso para demonstrar o quanto o processo de opressão pode ter uma múltipla combinação de fatores.

hecimento sistêmico eurocêntrico, a partir das experiências e realidades dos pesquisadores do Sul Global. Não há, aparentemente, diferenciação entre o uso das palavras descolonial ou decolonial, mas existem pesquisadores que manifestam sua preferência por um ou outro termo, como é o caso de Maria Lugones, que se refere ao feminismo que pesquisa como o "feminismo descolonial". Para fins de padronização do texto, serão utilizadas as expressões decolonialidade ou decolonial, mesmo nos trechos que se referem ao pensamento de Lugones, ressalvadas as citações diretas.

15 Lutiana Nacur Lorentz argumenta que: "o feminismo carreirismo-branco, ou de conveniência, ou "de perfumaria", na verdade é uma fraude ao real movimento porque tem como reais propósitos alavancar a carreira de específicas mulheres, em geral brancas, mas estas reproduzem os motes da sociedade patriarcal, machista e excludente tanto internamente, ou seja, nas próprias casas oprimem, empregadas domésticas em regra, negras e são refratárias (externamente) a libertação das mulheres (notadamente pobres) negando-lhes direitos sociais fundamentais, notadamente os trabalhistas". LORENTZ, Lutiana Nacur. Paradigmas e paradoxos dos movimentos de mulheres (feministas?) no Brasil. Em: MIRAGLIA, Lívia Mendes Moreira; TEODORO, Maria Cecília Máximo; SOARES, Maria Clara Persilva (Orgs.) Feminismo, trabalho e literatura: reflexões sobre o papel da mulher na sociedade contemporânea. Porto Alegre, RS: Editora Fi, pp. 286-313, 2020. Disponível em Disponível em: http://www.editorafi.org Acesso 8 mar. 2020.

16 Cf:: MATOS, Marlise. Movimento e teoria feminista: é possível reconstruir a teoria feminista a partir do Sul global? Revista de Sociologia Política. 2010, vol.18, n.36, pp.67-92. Disponível em: http://www.scielo.br/scielo.php?pid=S0104-44782010000200006\&script=sci_ abstract\&tlng=pt Acesso em 20 jun. 2018.

17 Cf.: nota de rodapé 14. 
Essa situação, de maneira semelhante à discriminação das mulheres brancas e homens negros, fazem as "mulheres de cor" ${ }^{\prime \prime}$, não-brancas, negras, mestiças, indígenas e asiáticas serem invisibilizadas perante esses dois outros referenciais. Para compreender isso, Lugones propõe o estudo do feminismo decolonial, que se justifica por ${ }^{19}$ :

[...] fornecer uma forma de compreender a opressão de mulheres subalternizadas através de processos combinados de racialização, colonização, exploração capitalista, e heterossexualismo. Minha intenção é enfocar na subjetividade/intersubjetividade para revelar que, desagregando opressões, desagregamse as fontes subjetivas e intersubjetivas de agenciamento das mulheres colonizadas. Chamo a análise da opressão de gênero racializada capitalista de "colonialidade do gênero". Chamo a possibilidade de superar a colonialidade do gênero de "feminismo descolonial".

Por meio de um conjunto de evidências extraídas das relações sociais mais íntimas ${ }^{20}$, Lugones propôs pensarmos como o processo de colonialidade de gênero teve efeitos diferentes sobre as sujeitas subalternas. Em especial, as mulheres não brancas e as de cor foram desumanizadas não somente pela dicotomia hierárquica homem e mulher, mas pela racialização, cujo processo pode ser mais facilmente compreendido com base em um simples exercício imaginário. Conforme Lugones ${ }^{21}$ :

Assim, "mulheres" refere-se a mulheres brancas. "Negro" refere-se a homens negros. Quando se tenta entender as mulheres na intersecção entre raça, classe e gênero, mulheres não brancas, negras, indígenas, asiáticas ou mestiças são seres impossíveis.

Essa compreensão possibilita o reconhecimento de outros fatores de opressão sobre as mulheres que vão além do dimorfismo biológico que enxerga o masculino em oposição ao feminino, a sexualidade do homem em contraposição à da mulher, resumindo-se no padrão do heterosexualismo e da dominação pelo patriarcado. Essas são as características visíveis ${ }^{22}$ do sistema de gênero moderno/colonial, tal como apresentado por Quijano.

Todavia, além disso, cabe pensar na interseccionalidade de gênero e de raça. Assim, quando Quijano propõe que uma das formas de dominação se dá pela organização do trabalho e de seus produtos (a riqueza que ele gera), pode-se pensar que a própria divisão do trabalho, quando compreendida com base no critério da racialização, consolidou o poder colonial e reafirmou novas formas de controle, especialmente a partir do desenvolvimento do sistema capitalista.

A respeito do trabalho assalariado, por exemplo, quando se pensa no sistema capitalista europeu, pode-se afirmar que ele era reservado quase que exclusivamente aos homens brancos nascidos naquele continente ${ }^{23}$.

18 Lugones explica que o termo se relaciona com o feminismo negro de origem norte-americana, cujas articulações foram propostas por "mulheres latinas dos Estados Unidos, asiáticas, chicanas, afro-americanas, ou indígenas norte-americanas". LUGONES, Maria. Rumo ao feminismo descolonial. Revista de Assuntos Feministas REF, Universidade Federal de Santa Catarina, Florianópolis, v. 22, nº. 03, setembro dezembro/2014, p. 942. Disponível em: https://periodicos.ufsc.br/index.php/ref/issue/view/2211/showToc Acesso em 23 set. 2017.

19 Cf.: LUGONES, Maria. Rumo ao feminismo descolonial. Revista de Assuntos Feministas REF, Universidade Federal de Santa Catarina, Florianópolis, v. 22, nº. 03, setembro dezembro/2014, p. 941. Disponível em: https://periodicos.ufsc.br/index.php/ref/ issue/view/2211/showToc Acesso em 23 set. 2017.

20 Nesse sentido, relações sociais mais íntimas não se refere ao sexo, mas às relações interpessoais entre pessoas mais próximas entre si.

21 Cf.: LUGONES, Maria. Rumo ao feminismo descolonial. Revista de Assuntos Feministas REF, Universidade Federal de Santa Catarina, Florianópolis, v. 22, nº. 03, setembro dezembro/2014, p. 942. Disponível em: https://periodicos.ufsc.br/index.php/ref/ issue/view/2211/showToc Acesso em 23 set. 2017.

22 Quijano defende que há elementos que marcam a colonialidade, sobretudo no cenário capitalista, como elementos que estruturam uma "classificação social universal". Entre eles citem-se: a raça e suas características fenotípicas, como a cor da pele. QUIJANO, Aníbal. Colonialidad del poder y clasificación social. Journal of world-systems research, v. 11, n. 2, 2000, p. 374. Disponível em: https:// www.lavaca.org/wp-content/uploads/2016/04/quijano.pdf Acesso em: 17 mai. 2020.

Lugones, no entanto, aponta que esses elementos por si só não compreendem todo o tipo de opressão dos dominadores, sobretudo quando se pensa na questão do gênero. LUGONES, Maria. Colonialidad y género, Tabula Rasa. Bogotá - Colombia, n. ${ }^{\circ}$ 9: 73-101, julio diciembre 2008. Disponível em: http://www.scielo.org.co/pdf/tara/n9/n9a06.pdf Acesso em 22 mai. 2020.

23 "A divisão do trabalho é completamente racializada e geograficamente diferenciada. Aqui, vemos a colonialidade do trabalho como um entrelaçamento cuidadoso11 de trabalho e raça". Tradução livre. LUGONES, Maria. Colonialidad y género, Tabula Rasa. Bogotá - Colombia, n. ${ }^{\circ}$ 9: 73-101, julio diciembre 2008, p. 80. Disponível em: http://www.scielo.org.co/pdf/tara/n9/n9a06.pdf 
Quando se pensa nos territórios fora do centro hegemônico, como o Brasil ao tempo do Império, as ocupações remuneradas eram exercidas pelos funcionários públicos, homens brancos europeus ou burgueses nascidos aqui.

De outro lado, no contexto da primeira Revolução Industrial, o trabalho produtivo das mulheres somente passou a ter valor para o sistema capitalista por ser considerado uma mão-de-obra mais barata que o trabalho dos homens. Paralelamente a isso, as mulheres continuavam sendo as responsáveis pelas tarefas de cuidado pessoal com a família, o que caracteriza o lado reverso do trabalho que se diz produtivo: o trabalho reprodutivo e não remunerado. Já no caso das mulheres negras, até a abolição da escravatura, sequer pode-se dizer que tinham uma relação de trabalho, porque eram consideradas mercadorias e seus serviços prestados não adentravam na esfera jurídica.

Assim, a interseccionalidade permite compreender que existem formas de controle do trabalho, por exemplo, que são moldadas pela racialização, ainda que sejam diferentes os contextos culturais dos países considerados hegemônicos e dos países das periferias. Essas subalternizações oprimem as mulheres das periferias, como é o caso das latinas e também as não brancas e, mais fortemente, as mulheres negras. Para pensar formas de resistências deve-se considerar que gênero e raça não são eixos estruturais desconectados. Isso, porque, a ideia de categorias limita a compreensão de discriminações em outras relações sociais mais complexas.

Nesse sentido, o feminismo negro tem como importante proposta permitir que as próprias sujeitas tidas como subalternas ocupem o lugar de fala ${ }^{24}$ nos debates sobre racismo e machismo, revelando o obscurantismo que, durante muito tempo, manteve o tratamento diferenciado dado à mulher negra nas sociedades modernas. Enquanto a mulher branca era cuidada e vista como delicada, associada a sentimentos como pureza e fragilidade, a negra trabalhava nas lavouras juntamente ao homem negro ou nos "afazeres domésticos" que não eram reservados à mulher branca, ocupando-se de servi-lo na mesa e na cama ${ }^{25}$.

Feitas essas ponderações, vejamos, então, como esse padrão de dominação, opressão e exploração se repete de uma maneira ressignificada pela divisão do trabalho na era do capitalismo, especialmente na esfera do trabalho reprodutivo das domésticas e diaristas brasileiras.

\section{Análise das normas de proteção trabalhista dos empregados domésticos}

No período colonial até abolição da escravidão, o trabalho doméstico no Brasil era exercido, preponderantemente, por povos de origem africana. Os portugueses traziam os negros de suas colônias na África para utilizá-los como mão de obra nos engenhos de açúcar e nas minas de ouro. Juntamente aos escravos homens, eram traficadas também escravas mulheres. A maioria delas era designada para o mesmo trabalho que eles. Outras, consideradas esteticamente mais bonitas, eram colocadas para trabalhar dentro das casas como mucamas, cozinheiras e amas de leite. Por essa razão, afirma-se que, no Brasil, a origem do trabalho doméstico é nitidamente escravocrata.

Mesmo com a abolição, em 1888, os negros não saíram da condição de escravos, passando a ocupar,

\footnotetext{
Acesso em 22 mai. 2020.

24 Um nome importante na discussão sobre o feminismo negro no Brasil é o de Djamila Ribeiro, acadêmica e filósofa, que discorre sobre "o lugar de fala" das mulheres negras. RIBEIRO, Djamila. O que é lugar de fala. São Paulo: Grupo Editorial Letramento, 2018. 25 Freyre concluiu que: "Não há escravidão sem depravação sexual. É da essência mesma do regime. Em primeiro lugar, o próprio interesse econômico favorece a depravação criando nos proprietários de homens imoderado desejo de possuir o maior número possível de crias. Joaquim Nabuco colheu em um manifesto escravocrata de fazendeiros as seguintes palavras, tão ricas de significação: "a parte mais produtiva da propriedade escrava é o ventre gerador". FREYRE, Gilberto. Casa-grande \& Senz̧ala: formação da família brasileira sob o regime da economia patriarcal. 48 ed. São Paulo: Global, 2003, p. 399.
} 
em sua grande maioria, a condição de trabalhadores informais, haja vista que mantinham suas relações de trabalho com os antigos senhores, às vezes em troca de comida e de onde morar. As oportunidades de trabalho lhes eram negadas, fosse pela desconformidade com o padrão estético europeu exigido pelos patrões, fosse porque mantê-los em trabalhos submissos perpetuaria os privilégios da classe burguesa que se formou durante o período imperial.

O Brasil pós-abolição manteve a situação de desproteção social dos domésticos e fomentou a prática da informalidade nesse tipo de prestação de serviços. Muito dessa situação se deu pela inexistência de uma legislação específica para a classe doméstica, não obstante esse tipo de trabalho tenha sido disciplinado muito antes pelas Ordenações do Reino e, posteriormente, tratado pelo Código Civil de $1916^{26}$ nos artigos que dispunham sobre locação de serviços. Em um e outro caso, a normatividade era inexpressiva, preocupando-se mais em delimitar as atividades que caracterizavam a profissão e as normas de convivência entre patrões e empregados que efetivamente assegurar um rol mínimo de direitos para a proteção desse tipo de relação de trabalho.

Em 1943 foi aprovada a Consolidação das Leis do Trabalho pelo Decreto n ${ }^{\circ} 5.452^{27}$, tido como marco histórico da institucionalização do Direito do Trabalho no Brasil. Entretanto, esse regramento não contemplou os domésticos, tampouco os trabalhadores rurais. Tal fato confirma o nascimento de um Direito do Trabalho "de exceção" 28 . No caso dos domésticos, essa lacuna normativa permaneceu até 1972, quando a Lei $\mathrm{n}^{\circ} 5.859^{29}$ disciplinou esse tipo de ocupação e determinou os seus direitos. Embora essa legislação já tenha sido revogada, vigorou por, aproximadamente, 43 anos e foi importante na consolidação de direitos dos trabalhadores domésticos, como as férias anuais remuneradas de vinte dias úteis, após cada doze meses de trabalho; a anotação de carteira de trabalho e a inscrição do empregado como segurado obrigatório da Previdência Oficial, regulamentados pelo Decreto n 71.885 de $1973^{30}$.

Passados mais de quinze anos, somente com o advento da Constituição Federal ${ }^{31}$, os trabalhadores domésticos tiveram novos direitos assegurados como salário mínimo, irredutibilidade de salário, décimo terceiro, repouso semanal remunerado, gozo de férias acrescidas de um terço, licença maternidade e paternidade, aviso prévio proporcional de no mínimo 30 dias e direito à aposentadoria. Posteriormente, com a Lei $n^{\circ}$ 10.208 de $2001^{32}$, assegurou-se o ingresso facultativo da categoria no programa do Fundo de Garantia por Tempo de Serviço (FGTS), que lhe dava acesso ao benefício do seguro-desemprego. E, em 2006, a Lei no $11.324^{33}$ passou a assegurou a estabilidade da gestante, o direito às férias de trinta dias, a proibição de descontos por utilidade e o direito aos feriados.

Em 2013 a Emenda Constitucional n ${ }^{\circ} 2^{34}$ ampliou direitos previstos na Constituição Federal, em espe-

26 Cf.: BRASIL. Código Civil. Lei n $n^{\circ}$ 3.071, de 1 janeiro de 1916. Disponível em: http://www.planalto.gov.br/ccivil_03/leis/ L3071impressao.htm Acesso em: 25 mai. 2020.

27 Cf.: BRASIL. Consolidação das Leis do Trabalho. Decreto n. ${ }^{\circ}$ 5.452, de 1 de maio de 1943. Disponível em http:/ / www.planalto.gov. br/ccivil_03/decreto-lei/del5452.htm Acesso em 25 mai. 2020.

28 Argumentam Cléber Lúcio de Almeida e Wânia Guimarães Rabello de Almeida que: “[...] as primeiras leis de proteção social eram verdadeiras leis de exceção, visto que careciam do sentido de universalidade, que somente se fez presente, mesmo assim ainda de forma restrita, após a edição da CLT (nesse sentido, o Direito do Trabalho também surgiu, no Brasil, como um direito de exceção)". ALMEIDA, Cleber Lúcio de; ALMEIDA, Wânia Guimarães Rabêllo de. Direito do Trabalho e Constituição: a constitucionalização do Direito do Trabalho no Brasil. São Paulo: LTr. 2017, p. 42.

29 Cf.: BRASIL. Lei n. ${ }^{\circ}$ 5.859, de 11 de dezembro de 1972. Disponível em: http://www.planalto.gov.br/ccivil_03/leis/15859.htm Acesso em: 25 mai. 2020.

30 Cf.: BRASIL. Decreto n. ${ }^{\circ}$ 71.885, de 9 de março de 1973. Disponível em: http://www.planalto.gov.br/ccivil_03/decreto/1970-1979/ D71885.htm Acesso em 25 mai. 2020.

31 Cf.: BRASIL. [Constituição (1988)]. Constituição da República Federativa do Brasil, de 5 de outubro de 1988. Disponível em http://www. planalto.gov.br/ccivil_03/constituicao/constituicao.htm Acesso em 25 mai. 2020.

32 Cf.: BRASIL. Lei n. ${ }^{\circ}$ 10.208, de 23 de março de 2001. Disponível em: http://www.planalto.gov.br/ccivil_03/leis/LEIS_2001/ L10208.htm Acesso em: 25 mai. 2020.

33 Cf.: BRASIL. Lei 11.324, de 19 de julho de 2006. Disponível em: http://www.planalto.gov.br/ccivil_03/_ato2004-2006/2006/lei/ 111324.htm Acesso em: 25 mai. 2020.

34 Cf.: BRASIL. Emenda Constitucional n. ${ }^{\circ}$ 72, de 2 de abril de 2013. Disponível em: http://www.planalto.gov.br/ccivil_03/constitui- 
cial a garantia máxima de duração da jornada, o pagamento de horas extras, o adicional noturno e a obrigatoriedade do FGTS. Entre os direitos assegurados, alguns tinham efeito e aplicabilidade imediata e vários outros dependiam de regulamentação. Somente em 2015 a regulamentação completa da categoria veio com a publicação da Lei Complementar $n^{\circ} 150^{35}$. A partir daí, passados dezoito anos após a promulgação da CR88, os trabalhadores domésticos foram formalmente equiparados aos demais trabalhadores.

A Lei Complementar no 150 de 2015 definiu os requisitos para a formação do vínculo de emprego do doméstico, afastando a insegurança jurídica que muitas vezes beneficiava empregadores, e regulamentou o rol de direitos ainda pendentes, como a relação de emprego protegida contra dispensa arbitrária ou sem justa causa; o seguro desemprego, em caso de desemprego involuntário; o recolhimento obrigatório para o FGTS; a remuneração do trabalho noturno superior ao diurno; o salário-família pago em razão do dependente do trabalhador de baixa-renda; a assistência gratuita aos filhos e dependentes, desde o nascimento até cinco anos de idade em creches e pré-escolas e o seguro contra acidentes de trabalho, a cargo do empregador, sem excluir a indenização a que este está obrigado, quando incorrer em dolo ou culpa.

Destaca-se que pesquisadores apontam que o Brasil foi o último país do Ocidente a abolir a escravidão e o que recebeu o maior número de escravos vindos da África, na comparação com outros também com passado escravocrata ${ }^{36}$. E a história da colonialidade e do colonialismo de poder demonstram que o trabalho doméstico é um dos maiores traços das desigualdades sociais nos povos que foram colonizados. A comprovação disso é que a Organização Internacional do Trabalho se preocupou desde a sua constituição com as condições desse trabalhador no mundo todo.

Em 1919, na Conferência da Paz, foram aprovados o Tratado de Versalhes e a criação da Organização Internacional do Trabalho - OIT, que mais tarde tornar-se-ia agência especializada da Organização das Nações Unidas - ONU. A finalidade principal da OIT é atuar como agente propositivo de normas internacionais que visam regulamentar as bases das relações de trabalho em nível global. Como consequência, a Organização incentiva a adoção de normas que assegurem condições decentes de trabalho dentro dos limites territoriais de Estados Nacionais.

Entretanto, mesmo existindo desde 1919, somente em $1^{\circ}$ de junho de 2011, na cidade de Genebra, ocorreu a $100^{a}$ sessão da Conferência Geral da Organização Internacional do Trabalho, que teve como resultado de uma de suas discussões a elaboração de uma Convenção sobre os Trabalhadores Domésticos. No ano seguinte, adotou-se a Recomendação no 201 que dispôs também sobre os trabalhadores domésticos.

Oficialmente, a Convenção $189^{37}$ passou a ter vigência em 2013 e, ao todo, 29 Estados-membros da OIT a ratificaram até o momento. O Brasil a ratificou somente em 2018, ou seja, passados cinco anos da sua aprovação na Conferência e mais três anos após a edição da Lei Complementar no 150 . A Convenção tem como premissa a equiparação dos direitos desses trabalhadores com os direitos dos demais empregados. Dentre os direitos estendidos, mencionam-se as horas de trabalho em número razoável, o descanso semanal remunerado de pelo menos 24 horas consecutivas, um limite mínimo de salário em dinheiro para evitar a servidão, a obrigatoriedade de informações claras sobre os termos e condições de emprego e o respeito aos princípios e aos direitos fundamentais no trabalho, incluindo a liberdade sindical e o direito à negociação coletiva.

Essa mora em regulamentar o trabalho doméstico confirma que a dominação dos tempos da colônia não ficou restrita ao imaginário dos sujeitos, mas se perpetuou na estrutura tanto da sociedade brasileira quanto

cao/emendas/emc/emc72.htm Acesso em: 25 mai. 2020.

35 Cf.: BRASIL. Lei Complementar n. 150 , de 2 de abril de 2013. Disponível em: http://www.planalto.gov.br/ccivil_03/leis/lcp/ lcp150.htm Acesso em: 25 mai. 2020.

36 Cf.: SCHWARCZ, Lilia. Brasil viveu um processo de amnésia nacional sobre a escravidão, diz historiadora. Entrevista concedida à Júlia Dias Carneiro. BBC Brasil no Rio de Janeiro. Disponível em: https://www.bbc.com/portuguese/brasil-44034767 Acesso em 29 mai. 2020.

37 Cf.: OIT-BRASIL. Convenção 189, de 16 de junho de 2011.Disponível em: http://www.oitbrasil.org.br/content/entra-em-vigorconvencao-sobre-trabalho-domestico-da-oit Acesso em: 25 mai. 2020. 
de outros países da periferia. No campo psicológico, pode-se afirmar que essas condições extrapolaram as relações interpessoais e alcançaram as relações coletivas em seu sentido macro, constituindo o chamado "racismo estrutural" ${ }^{38}$. Não obstante a discriminação nem sempre venha de forma direta de uma pessoa para a outra em razão da sua cor, ela permeia toda a estrutura social e perpetua um estado de subalternização de inferioridade do negro em relação ao branco.

No campo do mercado de trabalho, o padrão de inserção dos trabalhadores negros é pela informalidade e, consequentemente, os brancos ocupam mais postos de trabalhos formais, o que acaba interferindo sobremaneira na remuneração desses grupos. Os negros, sejam homens ou mulheres, ocupam os cargos mais mal remunerados do mercado de trabalho brasileiro, os quais, como regra, são preenchidos por pessoas com baixa escolaridade. Cria-se um círculo vicioso de relações de dominação, que são agravadas pela herança do patriarcalismo e têm nas mulheres não brancas, especialmente nas pretas e pardas ${ }^{39}$, profundas consequências no tocante à divisão do trabalho, como adiante veremos.

\section{Retrato da situação atual do mercado de trabalho das empregadas domésticas brasileiras}

Em 2017 os dados estatísticos publicados pela Instituto de Pesquisa Econômica Aplicada - IPEA ${ }^{40}$ sobre as desigualdades sociais no Brasil relativamente a gênero e raça demonstram que, de 1995 a 2015, a taxa de participação no mercado de trabalho ${ }^{41}$ de pessoas com mais de 10 anos de idade subiu de, aproximadamente, 73,5 milhões de trabalhadores para 104,5 milhões. Esse número traduz um percentual de 59,4\% de taxa de participação no mercado de trabalho, incluindo as pessoas ocupadas e não ocupadas, ou seja, o quociente entre a população economicamente ativa e a população total brasileira.

Tomando como referencial o último ano da pesquisa (2015), os homens somam, aproximadamente, 58,9 milhões, enquanto as mulheres os outros 45,7 milhões de trabalhadoras. No tocante à raça, os dados apontam que entre as mulheres, o número de negras empregadas ou a espera de uma colocação supera em cerca de 2,5 milhões o número de mulheres brancas, o que transformado em percentual significa dizer que no mercado de trabalho as mulheres negras representam aproximadamente $10 \%$ a mais que as brancas.

A análise desses números demonstra que o mercado de trabalho, importante ponto de confluência das relações de dominação pelo poder colonial e econômico do capitalismo, é marcadamente formado pela participação dos homens. Ou seja, os homens têm maior propensão a ocupar postos de trabalho ao invés das mulheres, mas que entre elas a maior participação é das negras e não das brancas.

Aparentemente, os dados revelam um paradoxo, porque, se o mercado de trabalho tem mais mulheres negras disponíveis, uma compreensão preliminar poderia resultar na conclusão de que essas trabalhadoras são mais valorizadas que as brancas. Todavia, não é o que se revela quando se analisa o tipo de ocupação dessas mulheres, a quantidade de horas trabalhadas e a sua remuneração.

Estudos que compararam a distribuição de trabalhadores dos anos de 2001 a 2012, analisados por La-

\footnotetext{
38 Interpretando as palavras de Sílvio Luiz de Almeida, racismo é um processo histórico, mas também político, que ao se perpetuar na organização social torna-se parte da sua estrutura, reproduzindo-se através das instituições públicas e privadas de uma sociedade. Assim, compreende-se que o racismo estrutural é um conceito que abrange o racismo institucional e tem nesse seu principal meio de propagação. ALMEIDA, Silvio Luiz de. O que é racismo estrutural? Belo Horizonte: Letramento, 2018.

39 Os negros no Brasil são referenciados nas pesquisas de institutos públicos como IBGE e IPEA com pretos ou pardos.

40 Dados sobre o mercado de trabalho. IPEA. Retrato das desigualdades de gênero e raça, 2017. Brasil. Disponível em: http://www.ipea. gov.br/retrato/index.html. Acesso em 25 mai. 2020.

${ }_{41}$ Refere à população economicamente ativa (PEA), cujo indicador que leva em conta tanto o universo de trabalhadores quanto o de quem está à procura de emprego.
} 
vinas, Cordilhas e Cruz ${ }^{42}$, apontam que o maior percentual de ocupação das mulheres nesse último ano refere-se ao setor de comércio, com 56\% do percentual de trabalhadoras contra 53\% e 40\% em relação à prestação de serviços e à administração pública, respectivamente. Assim, a mercantilização do trabalho feminino aponta que a maior parte delas continua ocupando ou funções mais mal pagas e consideradas à margem do processo produtivo.

É o caso das atividades do setor de comércio ou daquelas tidas como femininas e relacionados ao ato de servir, como o trabalho de cuidado, saúde e ensino. E poucas, muito poucas na verdade, ocupam os setores da economia tidos como mais importantes no processo produtivo, como a indústria, a construção civil, a mineração e a agropecuária. Os serviços de cuidado representam a marca da sociedade patriarcal, que não permite às mulheres se libertarem do julgo social, econômico e político dos homens. E nesse cenário de opressões com diferentes fontes de dominação, é preciso investigar a real situação das mulheres negras brasileiras.

Os dados estatísticos divulgados pela Agência da OIT no Brasil ${ }^{43}$ com base na Pesquisa Nacional de Amostra de Domicílios Contínua - PNADC, realizada no quarto trimestre de 2019, apontam que o Brasil tem, aproximadamente, 6,3 milhões de trabalhadores domésticos, dos quais 92,4\% são mulheres. Esse percentual é consideravelmente maior que a taxa de $80 \%$ que as mulheres representam no trabalho doméstico no mundo e mesmo dos $88 \%$, se analisada a realidade dos países da América Latina e Caribe, cujos passados foram escravocratas. As mulheres pretas e pardas representam $62 \%$ do total de trabalhadoras, o que nos autoriza concluir que a realidade das domésticas brasileiras espelha muito a condição econômica social e política daquelas mulheres.

Uma vez verificadas as principais ocupações das mulheres no mercado de trabalho e sua relação com a ideia de servidão típica de uma mentalidade da colonialidade do poder, passamos a análise de outros fatores de opressão, típicos do sistema econômico capitalista já mencionados, como a quantidade horas trabalhadas e a remuneração. No tocante ao primeiro, cumpre recordar as informações apresentadas anteriormente sobre a normatização do trabalho doméstico no Brasil.

Somente em 1972 foi assegurado o principal direito de qualquer trabalhador, ou seja, a formalização do vínculo com assinatura da CPTS, porta de entrada para outros direitos trabalhistas e previdenciários. Entretanto, pesquisas do Dieese analisadas por Ávila ${ }^{44}$ apontam que, mesmo com a formalização do vínculo, as empregadas mensalistas tiveram aumento na jornada de trabalho semanal, se comparadas com as domésticas que prestam serviço na informalidade, as diaristas. Os estudos comprovam que cerca de 30\% das domésticas empregadas trabalhavam mais de 44 horas semanais no ano de 2012.

Em 2013, a EC 72 assegurou o direito ao controle de jornada, todavia, sua regulamentação não foi suficiente para garantir o cumprimento do limite constitucional de 44 horas por semana. Ao contrário, estudos apontam que o trabalho das domésticas é sujeito a longas jornadas, muito em razão da prática cotidiana desses serviços e do custo baixo no pagamento das horas extras, consequência direta do valor da remuneração. O trabalho doméstico é um imperativo de qualquer grupo familiar, cujas necessidades exigem respostas imediatas, como as tarefas de cozinhar, limpar, lavar e cuidar pessoalmente dos incapacitados.

Soma-se a isso a natureza antecipada do trabalho, que requer a preparação de tarefas durante a jornada

\footnotetext{
42 Cf.: LAVINAS, Lena; CORDILHA, A. C.; CRUZ, G. F. Assimetrias de gênero no mercado de trabalho brasileiro: rumos da formalização. Em: ABREU, Alice Rangel de Paiva; HIRATA, Helena; LOMBARDI, Maria Rosa (Org.). Gênero e trabalho no Brasil e na França: perspectivas interseccionais. São Paulo: Boitempo, 2016, pp. 93 a 109.

43 Cf:: OIT. Convenção No 189: quatro pontos para entender a importância da promoção do trabalho decente para trabalhadoras domésticas em tempos de COVID-19. Brasília: OIT, 2020. Disponível em: https://www.ilo.org/brasilia/noticias/WCMS_742927/ lang--pt/index.htm Acesso em 25 mai. 2020.

44 Cf.: ÁVILA, Maria Betânia. O tempo do trabalho doméstico remunerado: entre cidadania e servidão. Em: ABREU, Alice Rangel de Paiva; HIRATA, Helena; LOMBARDI, Maria Rosa (Org.). Gênero e trabalbo no Brasil e na França: perspectivas interseccionais. São Paulo: Boitempo, 2016, pp. 137 a 146.
} 
de trabalho para que a família desfrute disso nos momentos de folga dessas trabalhadoras. E, ainda, a natureza retroativa dos afazeres para o cumprimento de atividades domésticas que não são feitas pela família, o que impõe uma sobrecarga de trabalho. Não se pode esquecer do distanciamento dos locais de trabalho e dos domicílios dessas empregadas, traço da ocupação territorial nos grandes centros urbanos, o que ainda consome mais tempo da classe operária. Essas condições caracterizariam uma "jornada extensiva, intensiva e intermitente para essas empregadas" 45 que tem, na apropriação do tempo, mais um elemento de controle dos corpos e subalternização.

No tocante à remuneração, os últimos dados coletados pela IPEA ${ }^{46}$ e divulgados em 2017 apontam, invariavelmente, que os salários mais baixos são das mulheres negras, tanto em comparação aos salários dos homens quanto das mulheres brancas. Analisando-se uma primeira tabela sobre a média mensal da remuneração dos trabalhadores domésticos, com e sem carteira assinada, e, segundo critérios de cor/raça e distribuição no território nacional, conclui-se que os salários mais baixos são pagos para as mulheres domésticas da região Nordeste, seguidos pelos salários dos estados da região Norte.

Essas mulheres recebiam $\mathrm{R} \$ 498,50$ e $\mathrm{R} \$ 579,40$, respectivamente, o que representava pouco mais da metade $(63 \%)$ e, aproximadamente, três quartos $(73 \%)$ do um salário mínimo do mesmo ano, cujo valor era de $\mathrm{R} \$ 788,00$. Em contrapartida, as melhores remunerações concentram-se nas regiões urbanas do Sudeste. Os valores abaixo do salário mínimo certamente indicam que as domésticas diaristas que trabalham na informalidade recebem menos. Isso, porque, os dados de uma segunda tabela sobre a remuneração da empregada doméstica com carteira assinada conforme número de domicílios trabalhados e critérios de raça/ cor, também tendo como referência o ano de 2015, indicam rendimento mensal médio $\mathrm{R} \$ 950,50$ para as negras e $\mathrm{R} \$ 1.045,20$ para as brancas.

Em ambos os casos, a remuneração das domésticas empregadas é maior que o salário mínimo, mas corresponde, aproximadamente, à metade da média salarial brasileira no mesmo período, de R $\$ 1.795,90$, paga a trabalhadores com carteira assinada, independentemente do critério sexo ou raça. Essa situação se agrava se forem considerados esses critérios na comparação. Não obstante essa diferença, chama mais atenção o fato de que mesmo em comparação às domésticas que têm a carteira assinada, as negras recebem cerca de $10 \%$ menos que as brancas.

A princípio, em valores globais, a diferença inferior a $\mathrm{R} \$ 100,00$ reais pode parecer insignificante, mas não se pode esquecer que ela se dá sem nenhum motivo legítimo aparente. Ao contrário, tão somente aponta fortes indícios de que a discriminação decorre de uma desvalorização dessas mulheres já enraizada na estrutura da sociedade brasileira em razão dos preconceitos coloniais com a raça, o sexo e o gênero, cujos critérios são obscuros e velados.

Quando a remuneração é combinada com o fator apropriação do tempo, a análise dos dados aponta que as domésticas com carteira assinada se ocupam desses trabalhos em uma média superior a 40 horas por semana, tanto no caso das brancas quanto das negras. Contudo, nas regiões Nordeste e Norte essas médias chegam próximo a 43 horas por semana, o que adianta a provável conclusão que o valor da hora de trabalho delas é menor, porque, mesmo trabalhando mais, ganham menos como mencionado anteriormente.

Outra parte do estudo aponta os dados relativos à jornada de trabalhos domésticos em que a média é superior a 40 horas por semana, mas não supera o limite de 44 horas por mês. Nesses casos, as trabalhadoras domésticas negras, empregadas ou diaristas, são as que mais trabalham além da $40^{a}$ hora. Os dados apontam que $25,10 \%$ das negras cumprem essa jornada, enquanto esse percentual é menor entre as brancas, ficando

45 Cf.: ÁVILA, Maria Betânia. O tempo do trabalho doméstico remunerado: entre cidadania e servidão. Em: ABREU, Alice Rangel de Paiva; HIRATA, Helena; LOMBARDI, Maria Rosa (Org.). Gênero e trabalho no Brasil e na França: perspectivas interseccionais. São Paulo: Boitempo, 2016, p. 141.

46 Cf.: Dados sobre o trabalho doméstico reunidos nas tabelas 7.11a1 e 7.11a2. IPEA. Retrato das desigualdades de gênero e raça, 2017. Brasil. Disponível em: http://www.ipea.gov.br/retrato/index.html Acesso em 25 mai. 2020. 
próximo de $24,4 \%$ do total.

Ainda que a duração dessas jornadas seja de difícil compreensão e a mensuração dos dados seja complexa, não se pode invisibilizar o fato de que os números apontam a desigualdade entre elas, em relação a eles, e entre as negras em relação às brancas. Isso confirma a hipótese apresentada: que os empregos mais socialmente desvalorizados são ocupados por mulheres negras, em geral, na prestação de serviços domésticos.

\section{Mais uma questão para refletir: a externalidade das opressões em tempos de pandemia pelo Coronavírus}

A realidade histórica vivenciada pelas mulheres negras domésticas no Brasil conduz a reflexões sobre o profundo nível de opressão imposto a elas, seja pela injustiça social que culmina na desvalorização do seu trabalho, seja pela apropriação dos seus corpos como "sujeitos menos" por outros que se enxergam como "sujeito mais". Entretanto, a invisibilidade dessa consciência pelas oprimidas e pelos opressores pode, muitas vezes, levar ao agravamento dessa situação. É o que mais recentemente presenciamos, como testemunhas da nossa própria história, face ao tratamento dado no Brasil às trabalhadoras domésticas.

A segunda década do século XXI se iniciou de forma conturbada em razão da pandemia global causada por um novo vírus popularmente conhecido como Corona, cuja doença é chamada COVID-19. Acredita-se que o Coronavírus tenha surgido em um mercado molhado ${ }^{47}$ ("wet market") na China, mais especificamente na província de Wuhan. Nesses mercados várias espécies de animais — incluindo animais silvestres — são comercializados para diversos usos, em especial para a alimentação. As condições sanitárias são precárias, o que contribui com a proliferação e a mutação de vírus. Wuhan foi o primeiro epicentro de contaminação e disseminação da doença COVID-19, e, em menos de seis meses, as contaminações pelo novo vírus já aconteciam em todos os sete continentes, quando foi reconhecido pelo Organização Mundial da Saúde - OMS como uma pandemia.

No Brasil a primeira morte registrada em decorrência do vírus foi de uma empregada doméstica de 63 anos de idade que há mais de 2 décadas trabalhava na mesma residência ${ }^{48}$. Os fatos apurados indicam que a patroa havia voltado de uma viagem da Itália, local que na época era o epicentro da doença. Ao retornar, manteve-se reclusa em casa, mas não dispensou a empregada, que tempos depois veio a falecer, sendo constatada a infecção por Coronavírus. A patroa, que manteve contato com os familiares da empregada após a piora do seu quadro de saúde, confessou a eles que também tinha a doença.

De março em diante, o número de mortes aumentou e foram adotadas medidas por alguns governadores e prefeitos para impedir a circulação do vírus, como o distanciamento social, mantendo em funcionamento apenas os serviços considerados essenciais. Além disso, foram impostas medidas de contenção na circulação de ônibus e outros meios de transporte. Essas providências, fundamentais para garantir a sobrevivência diante de uma ameaça sanitária global, impactaram, diretamente, a circulação de pessoas e, com isso, os rendimentos das atividades econômicas. Em decorrência, diversos trabalhadores foram demitidos, realocados para o trabalho home office ou tiveram seus contratos de trabalho suspensos.

Sabe-se que as trabalhadoras domésticas se submetem a riscos acentuados de contaminação, seja no uso do transporte público para o deslocamento até o local de trabalho, seja pelo tipo de atividade que as mantém em contato direto com outras pessoas. Assim, o ideal seria a dispensa remunerada do serviço, uma vez que

\footnotetext{
47 Trata-se de um mercado de produtos frescos que vende vegetais, legumes e frutas, além de destacar-se pelo comércio de carnes, animais vivos e frutos do mar acondicionados em tanques, decorrendo daí o nome "wet market".

48 Cf.: FENATRAD. Secretária-geral do Sindoméstico/Ba revela situações que as trabalhadoras domésticas estão enfrentando devido à Covid-19. Publicado no dia 8 de abril de 2020. Disponível em: https://fenatrad.org.br/2020/04/08/site-brasil-de-fato-secretaria-geral-dosindomestico-ba-revela-situacoes-que-as-trabalhadoras-domesticas-estao-enfrentando-devido-a-covid-19/ Acesso em 25 mai. 2020.
} 
não há como cogitar o trabalho a domićlio nesses casos. Muitos empregadores agiram dessa forma com respaldo na Medida Provisória 936 de 2020, a qual assegurou a suspensão do contrato de trabalho por até dois meses ou a redução da jornada de trabalho com pagamento proporcional do salário.

No primeiro caso, o doméstico tem direito ao recebimento do auxílio emergencial de $\mathrm{R} \$ 600,00$ pago pelo Governo. No segundo, o pagamento de uma parte do salário pelo empregador, durante três meses, proporcional ao montante $25 \%, 50 \%$ ou $70 \%$ acordado na redução da jornada, sendo a outra paga pelo Governo Federal, nos mesmos percentuais da redução, mas calculados sobre o valor do seguro-desemprego. Considerando-se o valor de $\mathrm{R} \$ 1.163,00$, que corresponde ao piso regional do salário do doméstico pago em São Paulo ${ }^{49}$ — o estado mais atingido no Brasil em número de mortes causados pela pandemia - tem-se perda salarial maior para esses trabalhadores. Isso em razão do fator de redução usado para o cálculo do seguro-desemprego $(0,8)$, que atinge mais aqueles que ganham menos ${ }^{50}$.

Uma pesquisa recente divulgada pela Associação Nacional dos Especialistas em Políticas Públicas e Gestão Governamental - ANESP ${ }^{51}$ aponta que 48\% das empregadas mensalistas foram dispensadas e estão recebendo algum tipo de pagamento. No entanto, 39\% delas continuam trabalhando normalmente e, portanto, estão expostas às condições de riscos de contaminação pelo vírus. Fato que é preocupante, porque, segundo dados da OIT, o Brasil é o país que possui o maior número de trabalhadores domésticos em todo o mundo ${ }^{52}$.

Alguns estados da Federação ${ }^{53}$ chegaram a editar medidas legislativas para tornar essencial a atividade doméstica, sem qualquer ressalva aos casos que realmente exigem a presença desse trabalhador, como as atividades dos cuidadores de idosos ou daqueles que dependem de assistência permanente. Acrescente-se, ainda, os trabalhadores que prestam serviços para outros trabalhadores cujas atividades são essenciais, como o pessoal da área da saúde, por exemplo. Tal fato motivou a Federação Nacional das Empregadas Domésticas - Fenatrad a pressionar os órgãos públicos e denunciar o ocorrido à impressa para que atitudes fossem tomadas.

O Ministério Público do Trabalho - MPT emitiu, então, uma recomendação, sem efeito punitivo, incentivando a suspensão do contrato desses trabalhadores, a não ser em casos de real necessidade como apontado pela Fenatrad. Ainda assim, estados como Ceará, Maranhão e Rio Grande do Sul descumpriram a decisão, tendo o Pará revisto o decreto que inseria a atividade de doméstico como trabalho essencial. Em 22 de maio de 2020, as domésticas se organizaram para pressionar novamente o MPT lançando um site para denúncias e pedidos de apoio para a campanha "Cuida de quem te cuida" ${ }^{4}$. Como demonstrado, a pandemia do Coronavírus escancarou um tratamento desumano dado aos trabalhadores domésticos em geral, majoritariamente formado por mulheres negras.

Entretanto, a proposta desse estudo não é inviabilizar a luta das mulheres em geral, como se fossem sujeitas em lados opostos. Por isso não se deve ignorar os fatos noticiados sobre o aumento de agressões às

\footnotetext{
49 Cf.: IDOMESTICA. Salário de Empregada Doméstica 2020 - Tabela Vigente. Disponível em: https://www.idomestica.com/tabelas/salario-empregada-domestica Acesso em 26 mai. 2020.

50 Cf.: BRASIL. Lei n $n^{\circ}$ 7.889, de 11 de janeiro de 1990. Disponível em: http://www.planalto.gov.br/ccivil_03/leis/L7998compilado. htm Acesso em: 25 mai. 2020.

51 CF.: ANESP. Covid19 e Trabalhadoras Domésticas. Por Juliana Macedo, Camile Mesquita, Maria Aparecida Chagas Ferreira, Cláudia Baddini e Natália Fontoura. Publicado em 21 abr. 2020. Disponível em: http://anesp.org.br/todas-as-noticias/2020/4/22/covid19-e-trabalhadoras-domsticas Acesso em 27 de mai. 2020.

52 Cf.: SENADO FEDERAL (Brasil). Equiparação de direitos faz cinco anos, mas covid-19 agrava desrespeito a domésticas. Brasília, DF: Agência Senado. Publicado em 28 mai. 2020. Disponível em: https://www12.senado.leg.br/noticias/infomaterias/2020/05/equiparacao-de-direitos-faz-cinco-anos-mas-covid-19-agrava-desrespeito-a-domesticas Acesso em 28 mai. 2020.

53 Cf.: BRASIL DE FATO. Reportagem de Vinícius Sobreira. Sindicato critica estados que incluíram domésticas em serviço essencial na quarentena. Recife. Publicado em 25 mai. 2020. Disponível em: https://www.brasildefato.com.br/2020/05/25/sindicato-critica-estadosque-incluiram-domesticas-em-servico-essencial-na-quarentena Acesso em 27 mai. 2020.

54 Cf.: FENATRAD. Fenatrad convoca categoria para pressionar o MPT através do site da Campanba 'Cuida de quem te cuida'. Publicada no dia 22 de maio de 2020. Disponível em: https://www.cuidadequemtecuida.bonde.org/ Acesso 26 mai. 2020.
} 
mulheres durante o isolamento social ${ }^{55}$, ou do esgotamento físico e mental delas em razão das horas dedicadas às atividades de cuidado durante a pandemia, seja nos afazeres do lar, seja acompanhando os filhos no aprendizado escolar remoto. Inclusive, a respeito das pesquisadoras brasileiras, as pesquisas iniciais apontam um impacto negativo para a produção acadêmica dessas mulheres no período do isolamento social ${ }^{56}$.

Ocorre que é importante que a reflexão desse processo de desumanização ${ }^{57}$ das domésticas seja colocada em evidência nesse momento, porque, a partir dessas realidades concretas, essas trabalhadoras podem tomar consciência das opressões que vivenciam. Também permite que essas sujeitas identifiquem as causas dessa situação e compreendam as formas de resistência, exigindo a melhoria de suas condições de vida. São ações de combate à exploração do trabalho e à desigualdade social, possíveis com a instituição de políticas públicas e privada, que beneficiam a sociedade de maneira geral.

Valendo-nos das lições de Paulo Freire, mas contextualizando-as com enfoque menos sexista e mais relacionado ao gênero, pode-se afirmar que, quando os oprimidos conhecem sua realidade opressora, tonar-se possível para eles pensar em recuperar a sua humanidade. Esse processo de reconhecimento crítico emerge de propostas como essa, de debater as diversidades, sem esquecer da interseccionalidade das violências sobre os povos colonizados, em especial, as mulheres negras. Trata-se de sinalizar ao oprimido uma pedagogia que possa não somente libertá-lo, mas libertar todas e todos da tentativa de serem "sujeitos mais" 58 .

\section{Considerações finais}

Como visto, não se pode compreender a realidade histórica das trabalhadoras domésticas sem revisitar os ensinamentos sobre poder colonial e seus desdobramentos a partir do conceito de colonialidade do gênero. Em ambos os casos, a resposta exige pensarmos no movimento feminista que colabore em prol da libertação das ações desumanizadoras sofridas por essas sujeitas ocultas, sem omitir a importância que cada um desses feminismos representa para a sua realidade concreta.

Por isso, apresentamos, neste artigo, especialmente, as origens dessa violência sobre as mulheres, sejam elas de dominação do seu saber, do seu ser ou do seu poder de resistir. Apresentamos, ainda, considerações sobre como o movimento feminista precisa compreender a interligação entre as questões de gênero, raça e sexo, a fim de construir uma resistência que seja coletivamente pensada para romper o novo colonialismo. O feminismo decolonial de Lugones aponta nesse sentido e acreditamos que seja um importante passo para o reconhecimento em si dos efeitos da racialização, do patriarcado e da colonialidade de gênero sobre as mulheres negras no Brasil.

Revelado esse obscurantismo sobre o feminismo negro decolonial, apontamos como a mora legislativa em relação à regulamentação do trabalho das domésticas agravou o cenário de desvalorização da profissão no imaginário da sociedade brasileira e na realidade por elas vivenciadas. Os dados relativos ao mercado de

55 Cf.: SENADO FEDERAL (Brasil). Observatório alerta para risco de aumento da violência doméstica na pandemia. Brasília, DF: Agência Senado. Publicado em 05 mai. 2020. Disponível em: https://www12.senado.leg.br/noticias/materias/2020/05/05/observatorioalerta-para-risco-de-aumento-da-violencia-domestica-na-pandemia Acesso em 28 mai. 2020.

56 CF.: UFMG. Produtividade de mulheres pesquisadoras é mais afetada pela pandemia. Publicado em 11 mai. 2020. Disponível em: https://ufmg.br/comunicacao/noticias/produtividade-de-pesquisadoras-mulheres-e-mais-afetada-pela-pandemia Acesso em: 27 de mai. 2020.

57 A desumanização para Paulo Freire se estabelece quando o sujeito é oprimido pelo opressor de tal forma que seja roubada a vocação, que no contexto do artigo, é entendida como a sua dignidade humana. Esse processo não oprime somente o oprimido, mas se volta também contra o opressor, como um paradoxo entre a existência do "ser menos" que só tem sentido em razão da existência “do ser mais". FREIRE, Paulo. Pedagogia do oprimido. 8. ed. Rio de Janeiro: Paz e Terra, p. 19, 1980. Disponível em: https://cpers. com.br/wp-content/uploads/2019/10/Pedagogia-do-Oprimido-Paulo-Freire.pdf Acesso em 26 mai. 2020.

58 Cf.: FREIRE, Paulo. Pedagogia do oprimido. 8. ed. Rio de Janeiro: Paz e Terra, 1980. Disponível em: https://cpers.com.br/ wp-content/uploads/2019/10/Pedagogia-do-Oprimido-Paulo-Freire.pdf Acesso em 26 mai. 2020. 
trabalho revelam que o Brasil é o país com o maior número de trabalhadores domésticos em todo mundo, a maioria deles mulheres negras. Soma-se a isso a demonstração com base em dados estatísticos oficiais de uma remuneração média bem aquém do valor pago aos homens, sejam eles empregados de quaisquer outros setores. Também demonstramos a diferença entre os valores pagos às brancas e às negras, cujo único indicativo é a situação de discriminatória pura e simples, como marca de uma opressão histórica sofrida por elas.

Como arremate, trouxemos para a discussão a situação dessas empregadas durante a pandemia por Coronavírus como forma de compreender, além da desumanização, o quanto a luta das massas oprimidas pode ser inviabilizada e o quanto essas mulheres podem ter seus corpos expostos ao risco de vida. Entretanto, avaliamos que esse também pode ser o momento para iniciar as ações de libertação, desde que a construção desse pensamento venha de todas, as feministas e as mulheres que continuam reféns do processo de violência colonial. O engajamento tanto das mulheres brancas quanto das não negras, aí compreendidas as latinas, asiáticas, indígenas, mestiças e africanas, torna o processo de desalienação mais natural e mais propenso a resultados positivos, pelos laços espirituais que fazem umas se reconhecerem nas outras e pela força de uma revolução do conhecimento que é feminina. Assim, caminharemos todas e todos para o "charme da liberdade no Ilê-Aiyê" 59 .

\section{Referências}

ALMEIDA, Cleber Lúcio de; ALMEIDA, Wânia Guimarães Rabêllo de. Direito do Trabalho e Constituição: a constitucionalização do Direito do Trabalho no Brasil. São Paulo: LTr. 2017.

. El capitalismo neoliberal y la alienación subjetiva y colonial de los trabajadores: Deseos y afectos en el mundo del trabajo. Revista chilena de Derecho del Trabajo y de la Seguridad Social. Vol. 10. Núm. 20, 2019, pp. 1-21. Disponível em: https://revistatrabajo.uchile.cl/index.php/RDTSS/article/view/54227/59293 Acesso em: 07 mar. 2020.

ALMEIDA, Silvio Luiz de. O que é racismo estrutural? Belo Horizonte: Letramento, 2018.

ANESP. Covid19 e Trabalhadoras Domésticas. Por Juliana Macedo, Camile Mesquita, Maria Aparecida Chagas Ferreira, Cláudia Baddini e Natália Fontoura. Publicado 21 abr. 2020. Disponível em: http:/ /anesp.org.br/ todas-as-noticias/2020/4/22/covid-19-e-trabalhadoras-domsticas Acesso em 27 de mai. 2020.

ARISTÓTELES. A política. São Paulo: Martin Claret, 2001.

ÁVILA, Maria Betânia. O tempo do trabalho doméstico remunerado: entre cidadania e servidão. Em: ABREU, Alice Rangel de Paiva; HIRATA, Helena; LOMBARDI, Maria Rosa (Org.). Gênero e trabalbo no Brasil e na França: perspectivas interseccionais. São Paulo: Boitempo, 2016, pp. 137-146.

BASTOS, Angélica Barroso; COSTA, Bárbara Amelize; VIEIRA ANDRADE, Daphne de Emílio Circunde; DAHAS, Débora Caetano; SOUTO, Gisleule Maria Menezes. Insurreição gênero nos espaços de poder. A representatividade feminina na política brasileira à luz da reforma eleitoral. Belo Horizonte: Motres, 2018.

BATTAGLIA, Felice. Filosofia do Trabalho. São Paulo: Saraiva, 1958.

BRASIL. [Constituição (1988)]. Constituição da República Federativa do Brasil, de 5 de outubro de 1988. Disponível em http://www.planalto.gov.br/ccivil_03/constituicao/constituicao.htm Acesso em 25 mai. 2020.

\footnotetext{
59 A referência final é retirada da letra da música “O mais belo dos belos” do Grupo Musical Ilê Aiyề", fundado em 1974, no bairro da Liberdade, em Salvador, Bahia. O bloco surgiu com o propósito de divulgar a cultura africana e com o tempo transformou-se em uma verdadeira instituição que promove ações em favor da população negra e carente da Bahia, sendo reconhecido nacional e internacionalmente como referencial de resistência e de transformação, que tem como marca registrada a comunicação pacificadora pela alegria das suas músicas. DICIONÁRIO CRAVO ALBIN DA MÚSICA POPULAR BRASILEIRA. Bloco Afro Ilê-Aiyêe. Disponível em: http://dicionariompb.com.br/bloco-afro-ile-aiye/dados-artisticos Acesso em 30 mai. 2020.
} 
BRASIL. Código Civil. Lei n 3.071, de 1 janeiro de 1916. Disponível em: http://www.planalto.gov.br/ccivil_03/leis/L3071impressao.htm Acesso em: 25 mai. 2020.

Consolidação das Leis do Trabalho. Decreto n $n^{\circ}$ 5.452, de 1 de maio de 1943. Disponível em http:/ / www.planalto.gov.br/ccivil_03/decreto-lei/del5452.htm Acesso em 25 mai. 2020.

Lei $n^{\circ}$ 5.859, de 11 de dezembro de 1972. Disponível em: http://www.planalto.gov.br/ccivil_03/ leis/15859.htm Acesso em: 25 mai. 2020.

Decreto $n^{\circ}$ 71.885, de 9 de março de 1973. Disponível em: http://www.planalto.gov.br/ccivil_03/ decreto/1970-1979/D71885.htm Acesso em 25 mai. 2020.

Lei $n^{\circ}$ 7.889, de 11 de janeiro de 1990. Disponível em: http://www.planalto.gov.br/ccivil_03/leis/ L7998compilado.htm Acesso em: 25 mai. 2020.

Lei $n^{\circ}$ 10.208, de 23 de marco de 2001. Disponível em: http://www.planalto.gov.br/ccivil_03/leis/ LEIS_2001/L10208.htm Acesso em: 25 mai. 2020.

Lei 11.324, de 19 de julho de 2006. Disponível em: http://www.planalto.gov.br/ccivil_03/_ato20042006/2006/lei/111324.htm Acesso em: 25 mai. 2020.

Emenda Constitucional n 72, de 2 de abril de 2013. Disponível em: http://www.planalto.gov.br/ccivil_03/constituicao/emendas/emc/emc72.htm Acesso em: 25 mai. 2020.

Lei Complementar n 150, de 2 de abril de 2013. Disponível em: http://www.planalto.gov.br/ccivil_03/leis/lcp/lcp150.htm Acesso em: 25 mai. 2020.

BRASIL DE FATO. Reportagem de Vinícius Sobreira. Sindicato critica estados que incluíram domésticas em serviço essencial na quarentena. Recife. Publicado 25 mai. 2020. Disponível em: https://www.brasildefato.com. $\mathrm{br} / 2020 / 05 / 25 /$ sindicato-critica-estados-que-incluiram-domesticas-em-servico-essencial-na-quarentena Acesso em 27 mai. 2020.

DICIONÁRIO CRAVO ALBIN DA MÚSICA POPULAR BRASILEIRA. Bloco Afro Ilê-Aiyê. Disponível em: http://dicionariompb.com.br/bloco-afro-ile-aiye/dados-artisticos Acesso em 30 mai. 2020.

DUSSEL, Enrique. Europa, modernidad y eurocentrismo. Em: LANDER, Edgardo (coord.). La colonialidad del saber: eurocentrismo y ciencias sociales, perspectivas latino-americanas. Buenos Aires: Clacso, 2000, pp. 24-33. Disponível em: http://biblioteca.clacso.edu.ar/clacso/sur-sur/20100708040738/4_dussel.pdf Acesso em 17 mai. 2020.

FENATRAD. Secretária-geral do Sindoméstico/Ba revela situações que as trabalhadoras domésticas estão enfrentando devido à Covid-19. Publicado 8 abr. 2020. Disponível em: https://fenatrad.org.br/2020/04/08/site-brasil-de-fato-secretaria-geral-do-sindomestico-ba-revela-situacoes-que-as-trabalhadoras-domesticas-estao-enfrentando-devido-a-covid-19/ Acesso em 25 mai. 2020.

Fenatrad convoca categoria para pressionar o MPT através do site da Campanba 'Cuida de quem te cuida'. Publicada 22 de mai. 2020. Disponível em: https://www.cuidadequemtecuida.bonde.org/ Acesso 26 mai. 2020.

FREIRE, Paulo. Pedagogia do oprimido. 8. ed. Rio de Janeiro: Paz e Terra, 1980. Disponível em: https:/ / cpers. com.br/wp-content/uploads/2019/10/Pedagogia-do-Oprimido-Paulo-Freire.pdf Acesso em 26 mai. 2020.

FREYRE, Gilberto. Casa-grande \& Senzala: formação da família brasileira sob o regime da economia patriarcal. 48 ed. São Paulo: Global, 2003.

IDOMESTICA. Salário de Empregada Doméstica 2020 - Tabela Vigente. Disponível em: https:/ /www.idomestica.com/tabelas/salario-empregada-domestica Acesso em 26 mai. 2020. 
IPEA. Retrato das desigualdades de gênero e raça, 2017. Brasil. Disponível em: http://www.ipea.gov.br/retrato/ index.html. Acesso em 25 mai. 2020.

LAVINAS, Lena; CORDILHA, A. C.; CRUZ, G. F. Assimetrias de gênero no mercado de trabalho brasileiro: rumos da formalização. Em: ABREU, Alice Rangel de Paiva; HIRATA, Helena; LOMBARDI, Maria Rosa (Org.). Gênero e trabalho no Brasil e na França: perspectivas interseccionais. São Paulo: Boitempo, 2016, pp. 93 a 109.

LORENTZ, Lutiana Nacur. Paradigmas e paradoxos dos movimentos de mulheres (feministas?) no Brasil. Em: MIRAGLIA, Lívia Mendes Moreira; TEODORO, Maria Cecillia Máximo; SOARES, Maria Clara Persilva (Orgs.) Feminismo, trabalho e literatura: reflexões sobre o papel da mulher na sociedade contemporânea. Porto Alegre, RS: Editora Fi, 2020, pp. 286-313. Disponível em Disponível em: http://www.editorafi.org Acesso em: 8 mar. 2020.

LUGONES, Maria. Colonialidad y género, Tabula Rasa. Bogotá - Colombia, nº.9, pp. 73-101, julio diciembre 2008. Disponível em: http://www.scielo.org.co/pdf/tara/n9/n9a06.pdf Acesso em 22 mai. 2020.

Maria. Rumo ao feminismo descolonial. Revista de Assuntos Feministas REF, Universidade Federal de Santa Catarina, Florianópolis, v. 22, nº. 03, pp. 935-925, setembro dezembro/2014. Disponível em: https://periodicos.ufsc.br/index.php/ref/issue/view/2211/showToc Acesso em: 23 set. 2017.

MATOS, Marlise. Movimento e teoria feminista: é possível reconstruir a teoria feminista a partir do Sul global? Revista de Sociologia Política, vol.18, n.36, pp.67-92, 2010. Disponível em: http://www.scielo.br/scielo. php?pid=S0104-44782010000200006\&script=sci_abstract\&tlng=pt Acesso em 20 jun. 2018.

MIGNOLO, Walter. MIGNOLO, Walter. Postoccidentalismo: el argumento desde América Latina. Em: CASTRO-GÓMEZ, Santiago \& MENDIETA, Eduardo (coords.). Teorías sin disciplina: latinoamericanismo, poscolonialidad y globalización en debate. México: Miguel Ángel Porrúa, pp. 26-49, 1998. Disponível em: http://people.duke.edu/ wmignolo/InteractiveCV/Publications/Teoriassindisciplina.pdf Acesso em: 17 mai.2020.

OIT-BRASIL. Convenção 189, de 16 de junho de 2011.Disponível em: http://www.oitbrasil.org.br/content/ entra-em-vigor-convencao-sobre-trabalho-domestico-da-oit Acesso em: 25 mai. 2020.

OIT. Convenção No 189: quatro pontos para entender a importância da promoção do trabalho decente para trabalhadoras domésticas em tempos de COVID-19. Brasília: OIT, 2020. Disponível em: https://www.ilo. org/brasilia/noticias/WCMS_742927/lang--pt/index.htm Acesso em 25 mai. 2020.

QUIJANO, Aníbal. Colonialidad y modernidad-racionalidad. Perú Indígena, ano 29, pp. 11-92, 1992. Disponível em: https://www.lavaca.org/wp-content/uploads/2016/04/quijano.pdf Acesso em: 17 mai. 2020.

Aníbal. "Colonialidad del poder y clasificación social". Journal of world-systems research, v. 11, n. 2 , pp. 342-386, 2000. Tradução livre. Disponível em: https://www.lavaca.org/wp-content/uploads/2016/04/ quijano.pdf Acesso em: 17 mai. 2020.

RIBEIRO, Djamila. O que é lugar de fala. São Paulo: Grupo Editorial Letramento, 2018.

SANTOS, Boaventura de Sousa. Para além do pensamento abissal: das linhas globais a uma ecologia de saberes. Novos estud. - CEBRAP, São Paulo, n. 79, pp. 71-94, Nov. $2007 . \quad$ Disponível em: http:/ /www.scielo.br/scielo.php?script=sci_arttext\&pid=S0101-33002007000300004\&lng $=$ en\&nrm $=$ iso Acesso em 17 mai. 2020.

SCHWARCZ, Lilia. Brasil viveu um processo de amnésia nacional sobre a escravidão, diz historiadora. Entrevista concedida à Júlia Dias Carneiro. BBC Brasil no Rio de Janeiro. Disponível em: https://www.bbc.com/ portuguese/brasil-44034767 Acesso em: 29 mai. 2020. 
SENADO FEDERAL (Brasil). Observatório alerta para risco de aumento da violência doméstica na pandemia. Brasília, DF: Agência Senado. Publicado 05 mai. 2020. Disponível em: https://www12.senado.leg.br/noticias/ materias/2020/05/05/observatorio-alerta-para-risco-de-aumento-da-violencia-domestica-na-pandemia Acesso em 28 mai. 2020.

Equiparação de direitos faz. cinco anos, mas covid-19 agrava desrespeito a domésticas. Brasília, DF: Agência Senado. Publicado 28 mai. 2020. Disponível em: https://www12.senado.leg.br/noticias/infomaterias/2020/05/equiparacao-de-direitos-faz-cinco-anos-mas-covid-19-agrava-desrespeito-a-domesticas Acesso em 28 mai. 2020.

TEODORO, Maria Cecília Máximo; OLIVEIRA, M. P. S. Felicidade: A mais-valia da modernidade líquida. Em: $V$ ENCONTRO DA RENAPEDTS - Rede Nacional de Grupos de Pesquisa e Extensão em Direito do Trabalho e Seguridade Social, 2019, Rio de Janeiro. TRABALHO, DEMOCRACIA E DIREITOS: Desafios epistêmicos para a desmercantilização do labor humano. Belo Horizonte: Virtualis, v. 1, p. 286-287, 2019.

UFMG. Produtividade de mulheres pesquisadoras é mais afetada pela pandemia. Publicado 11 mai. 2020. Disponível em: https://ufmg.br/comunicacao/noticias/produtividade-de-pesquisadoras-mulheres-e-mais-afetada-pela-pandemia Acesso em: 27 de mai. 2020. 
Para publicar na revista Brasileira de Políticas Públicas, acesse o endereço eletrônico www.rbpp.uniceub.br

Observe as normas de publicação, para facilitar e agilizar o trabalho de edição. 